\title{
Regional stagnation of the western Keewatin ice sheet and the significance of meltwater corridors and eskers, northern Canada
}

\author{
D.R. Sharpe, J.-E. Lesemann, R.D. Knight, and B.A. Kjarsgaard
}

\begin{abstract}
The glacial land system of western Keewatin region, northern Canada, consists of three significant events: (1) regional emplacement of subglacial sediments, mainly till; (2) landscape erosion with development of an integrated, anabranched network of meltwater drainage routes leading to meltwater corridors; and (3) deposition of an extensive array of eskers, and related landforms, within meltwater corridors. Integration of extensive field observations, mapping, and remotely sensed data allow us to link scoured bedrock and till surfaces, truncated drumlins, scour pits, glaciofluvial terraces, boulder lags, and a large-scale network of corridors, as part of regional meltwater erosion events. The network of long ( 100-200 km), relatively wide ( 1-3 km) meltwater corridors record confined subglacial erosion that scoured sediment (and bedrock) prior to glaciofluvial sedimentation (predominately eskers). Despite considerable sediment erosion along meltwater corridors, moraines and other ice-marginal deposits are rarely observed on the western Keewatin landscape. The absence of these features is inconsistent with deglacial models relying on step-wise active retreat of the ice margin. Instead, we propose that deglaciation of the western Keewatin sector of the Laurentide Ice Sheet was predominantly controlled by regional thinning and stagnation. These findings raise fundamental questions about deglacial patterns and processes and thus suggest that further evaluation and revision of existing models of deglacial chronology for this sector of the Laurentide Ice Sheet is needed.
\end{abstract}

Key words: meltwater corridors, eskers, deglacial processes, regional stagnation, Keewatin, Laurentide Ice Sheet.

Résumé : Le système glaciaire terrestre de la région du Keewatin occidental du Canada septentrional témoigne de trois épisodes importants, à savoir : (1) la mise en place régionale de sédiments infraglaciaires, principalement des tills, (2) l'érosion du paysage accompagnée de la formation d'un réseau anastomosé intégré de voies de vidange des eaux de fonte menant à des corridors d'eaux de fonte et (3) le dépôt d'un vaste réseau d'eskers et de reliefs reliés dans les corridors d'eaux de fonte. L'intégration d'abondantes observations de terrain et données cartographiques et de télédétection permet de relier des surfaces de roc et de till affouillées, des drumlins tronqués, des fosses d'affouillement, des terrasses fluvioglaciaires, des résidus de déflation formés de blocs et un vaste réseau de corridors résultant d'épisodes régionaux d'érosion par les eaux de fonte. Le réseau de corridors d'eaux de fonte longs ( 100-200 km) et relativement larges ( 1-3 km) témoigne d'une érosion infraglaciaire confinée qui a affouillé les sédiments (et le roc) avant la sédimentation fluvioglaciaire (principalement sous forme d'eskers). Malgré l'importante érosion de sédiments le long des corridors d'eaux de fonte, des moraines et autres dépôts proglaciaires sont rarement observés dans le paysage du Keewatin occidental. L'absence de ces éléments ne concorde pas avec des modèles de déglaciation reposant sur le retrait actif par étapes de la marge du glacier. Nous proposons plutôt que l'amincissement et la stagnation à l'échelle régionale étaient les principaux contrôles de la déglaciation du secteur du Keewatin occidental de l'Inlandsis laurentien. Ces constatations soulèvent des questions fondamentales sur les motifs et processus de déglaciation et donnent donc à penser qu'une évaluation plus poussée et une révision des modèles existants de la chronologie de la déglaciation pour ce secteur de l'Inlandsis laurentien sont nécessaires. [Traduit par la Rédaction]

Mots-clés : corridors d'eaux de fonte, eskers, processus de déglaciation, stagnation régionale, Keewatin, Inlandsis laurentien.

\section{Introduction}

The Keewatin sector of the former Laurentide Ice Sheet (LIS) has played a prominent role in our understanding of glacial advance and retreat patterns of the ice sheet (e.g., Prest 1969; Dyke and Prest 1987a). Landform mapping has been the primary source of data supporting patterns for ice sheet advance and retreat, later supported by chronological data (Dyke and Prest 1987b; Dyke et al. 2003). Competing hypotheses of ice retreat processes and patterns centre around the possibility of active, sequential retreat of the LIS versus a more passive retreat hypothesis favouring stagnation of the LIS in portions of western Keewatin (Shilts 1985; Aylsworth and Shilts 1989a). Elucidating these questions offers insights into ice sheet dynamics and the potential behaviour of modern ice sheets currently undergoing decay. As well, synoptic paleo-ice sheet reconstructions offer crucial process constraints on numerical ice sheet models (e.g., Tarasov and Peltier 2004; Tarasov et al. 2012).

Early exploration (Tyrell 1902) and air photo analysis of barren land terrain (e.g., Wilson 1939) revealed an extensive westward

Received 10 July 2020. Accepted 25 March 2021.

D.R. Sharpe, R.D. Knight, and B.A. Kjarsgaard. Geological Survey of Canada, 601 Booth Street, Ottawa, ON K1A 0E8, Canada.

J.-E. Lesemann. Department of Earth Science, Vancouver Island University, 900 Fifth Street, Nanaimo, BC, Canada.

Corresponding author: David R. Sharpe (email: david.sharpe@canada.ca).

Copyright remains with the author(s) or their institution(s). This work is licensed under a Creative Commons Attribution 4.0 International License (CC BY 4.0), which permits unrestricted use, distribution, and reproduction in any medium, provided the original author(s) and source are credited. 
Fig. 1. Regional divergent esker array (Aylsworth et al. 2012) provides context for the study area focus on eskers and bounding corridors. Western Keewatin study area ( 130 $000 \mathrm{~km}^{2}$ ) extends from west of Dubawnt Lake (D.L.), north of Great Slave Lake (GSL) to Snap Lake (SL) and Lac de Gras (LD), within a network of eskers and flow tracts of the western Keewatin sector of the Laurentide Ice Sheet (EA, East Arm flow tract; Shaw et al. 2010). Note sparseness of large moraines; Chantrey (C) and McAlpine (M) moraines are primarily stratified glaciofluvial sediment. Inset image: corridor (between dashed lines; $1 \mathrm{~km}$ across, mid scene) truncates drumlin field and has an inset esker (white ridges), elements that represent the conceptual terrain model for the esker (and inferred corridor) array across the Keewatin area west of the Keewatin Ice Divide (KID). d, drumlins; E, esker; R, bedrock. Locations of a series of scaled maps, Figs. 4 (study area), 5, 7, 8 (within 7), and 10, are noted. The study area consists of 12 complete and 2 half 1:250 000 topographic sheets (see thin grid within the study area). (Flow tracts from Shaw et al. 2010.)

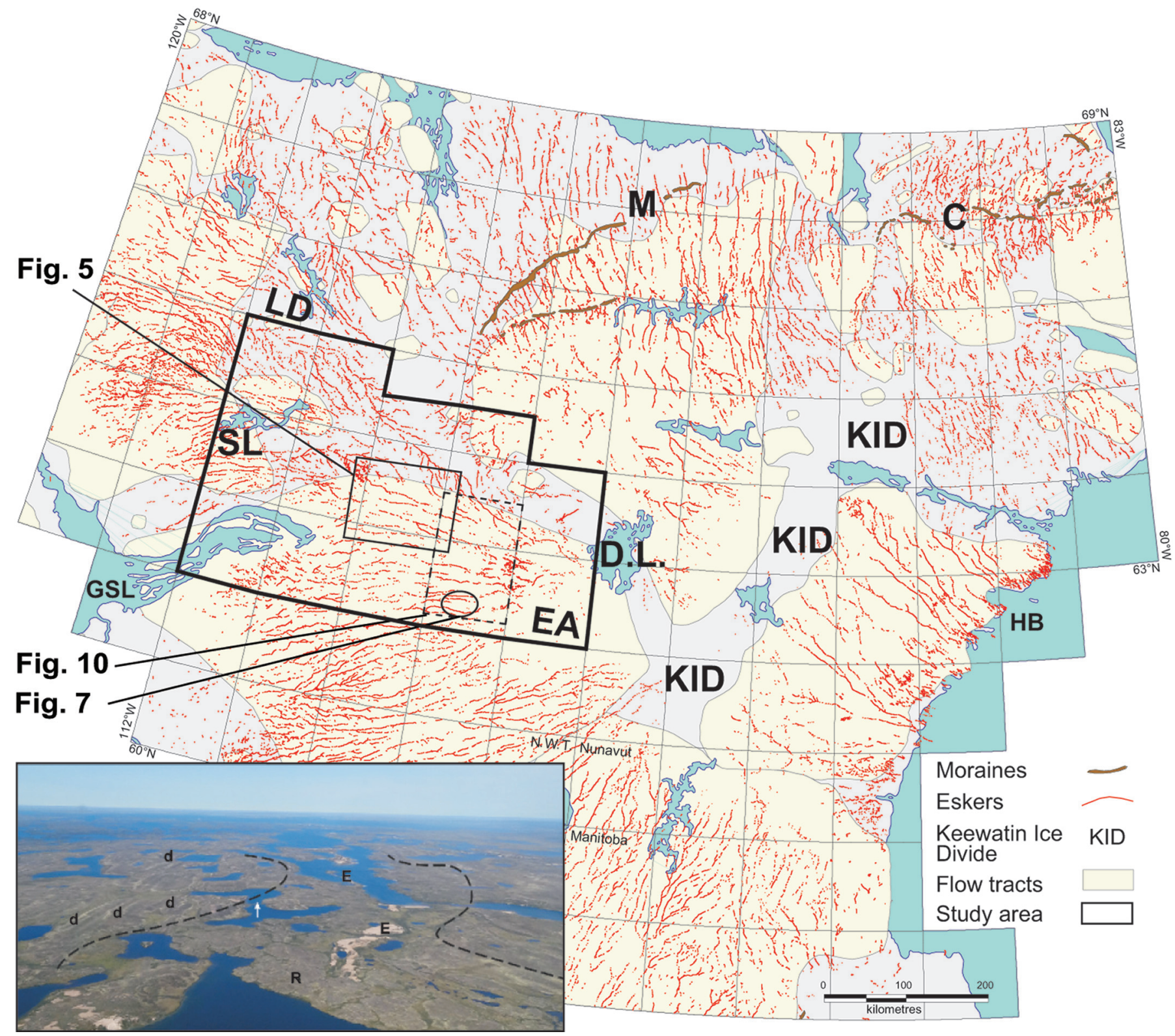

radial pattern of landforms (especially eskers and drumlins) centred around the Keewatin Ice Divide (KID; Lee et al. 1957; Lee 1959; Shilts 1985; Aylsworth and Shilts 1989a; Fig. 1). Regional mapping from aerial photographs led Wilson (1939) to propose a time-transgressive model of esker development in short segments, sourced from the local till as the ice front retreated, step by step. Due to the Keewatin-wide extent of the esker network (Fig. 1), Wilson's time-transgressive ice retreat model was applied across the Keewatin region. Craig and Fyles (1960) expanded the active ice-marginal retreat model, proposing that most striations, till, and drumlins were generated beneath "a zone a few miles wide near the ice margin” (Craig 1964, p. 7), as ice retreated across Keewatin, with landform creation continuing and extending to the KID (Lee 1959). These early notions persist through the literature and frame many subsequent ice-marginal reconstructions (Dyke and Dredge 1989; Dyke et al. 2003; Dyke 2004; Storrar et al. 2014a, 2014b; Lewington et al. 2020a, 2020b).

In contrast, integrated regional esker network studies led to inferences of regional ice stagnation (Shilts et al. 1979; Shilts 1985; Aylsworth and Shilts 1989a, 1989b). While Dyke and Dredge (1989) considered that stagnation may have occurred where a crevassed zone of the glacier became detached from the main 
Fig. 2. Meltwater corridor near Lac de Gras shows contrast between smooth till uplands (T) outside of modified and scoured areas inside meltwater corridor (MC). Meltwater-scoured bedrock (S) has a broken cover of glaciofluvial deposits, transverse ridges (R), crude gravel dunes (d), and esker (E). Note scoured, remnant till veneer (t) on corridor floor. Partially modified till (TM) and small drumlins (D) occur next to main scoured corridor. The till surface (T) shows little effect of meltwater erosion or deposition, in contrast to modified (washed) till (TM). Note that till modification can occur beyond the well-marked corridor margins. Direction of subglacial meltwater flow indicated by large arrow. (Energy, Mines and Resources (Government of Canada) vertical air photo A15495-113). From Rampton 2000 , fig. 3.

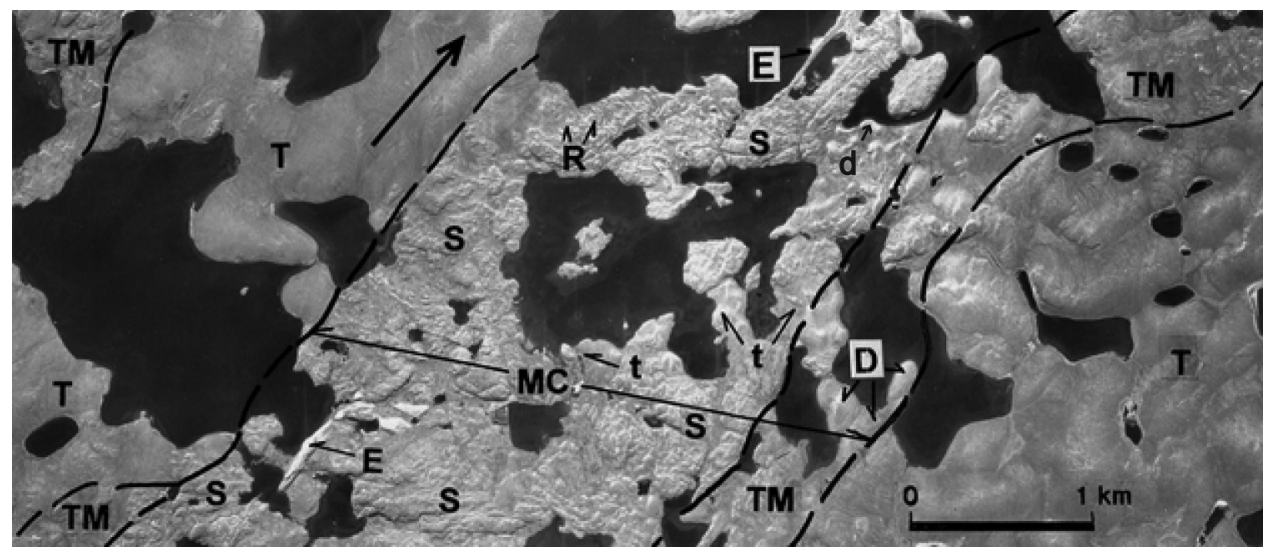

glacier front during retreat, the regional stagnation concept would not re-appear until later work by Stokes and Clark (2003) on flow sets and ice stream shutdown.

Despite contrasting and largely unresolved (untested) views of deglacial style and pattern, the sequential, ice-marginal retreat model is implicitly accepted in synoptic representations of LIS retreat patterns (e.g., Dyke et al. 1989). This protocol links icemarginal landforms to isochrones, which are central to the deglacial chronology for the Keewatin sector of the LIS (Dyke 2003, 2004; Dyke et al. 2003; Dalton et al. 2020). For western Keewatin, these isochrones are defined using very limited chronologic data.

In this paper, we re-examine the step-wise ice marginal retreat model for the western Keewatin sector of the LIS with focus on two key elements: (1) the regional pattern and glaciohydraulic significance of a prominent and extensive network of meltwater corridors $^{1}$ and their inset eskers across the western Keewatin landscape; (2) expected patterns of ice-marginal landforms indicative of former ice margins. Based on our findings, we propose that regional stagnation was more prominent during deglaciation (e.g., Shilts et al. 1979; Shilts 1985) of the western Keewatin region rather than step-wise ice-marginal retreat.

\section{Regional setting}

Bedrock of the Slave and Churchill tectonic provinces consist mainly of durable granitoids, metamorphosed volcano-sedimentary rocks, and gneiss, in part overlain by friable Thelon sandstone (Kjarsgaard et al. 2013a). This part of the Canadian Shield was the setting for an extensive field-based surficial sediment sampling and analysis campaign (foot and aircraft traverses) across $\sim 130000 \mathrm{~km}^{2}$ of the glaciated terrain of western Keewatin (Fig. 1).

Recent remote sensing and mapping studies provide unprecedented synoptic views of vast areas of Canada's glaciated terrain (e.g., Kleman et al. 2006; Shaw et al. 2010; Stokes and Clark 2003; Stokes et al. 2006; Storrar et al. 2013, 2014b; Storrar and Livingstone 2017; Lewington et al. 2019; 2020a; Livingstone et al. 2020). They complement local-scale field studies that have identified components of these glaciated landscapes. For example, "meltwater corridors" first mapped by Lord and Barnes (1954), and later interpreted and formally named by Rampton (2000) are now mapped regionally using remotely sensed data (e.g., Lewington et al. 2020a, 2020b). Remote sensing data, although high quality, benefits greatly from ground truth studies that incorporate surface material test pits, clast composition, frequency, and shape data. These data constrain the morpho-sedimentary character of key elements of Keewatin terrains, such as modified and scoured till and rock surfaces transitioning to sediment and bedrockfloored meltwater corridors with inset eskers (e.g., Dredge et al. 1995; Rampton 2000; Rampton and Sharpe 2014; Sharpe et al. 2017; Utting et al. 2009). The remotely sensed network of mapped eskers (Fig. 1) provides a credible prediction of the regional extent of corridors that occur in association with the esker network. Meltwater corridors and eskers, inset within extensive drumlins swarms, help define regional flow tracts (Fig. 1; Shaw et al. 2010; Lewington et al. 2020a). These have been linked to glaciodynamic events such as paleo-ice streams (e.g., De Angelis and Kleman 2005; Margold et al. 2018; Stokes and Clark 2003; Stokes et al. 2006) or to meltwater floods (Brennand and Shaw 1994; Rampton 2000), both regional events that may provide insights on the style of deglaciation.

The significance of meltwater corridors to deglacial processes

Meltwater corridors have been reported in the Keewatin region since the advent of aerial photographs (Wilson 1939) and their field identification (Lord and Barnes 1954; Lee 1959; Craig 1964). Detailed field work improved their characterization in Keewatin (e.g., St-Onge 1984; Dredge et al. 1995; Ward et al. 1997; Rampton 2000; Utting et al. 2009; Rampton and Sharpe 2014; Sharpe et al. 2014, 2017; Campbell et al. 2016, 2019). Rampton (2000) first illustrated key morpho-sedimentary features of meltwater corridors (Fig. 2). His detailed corridor mapping near Lac de Gras, Northwest Territories, showed a clear erosional boundary between smooth till uplands and incised relatively sediment-free corridors characterized by scoured bedrock areas, sometimes with remnant till veneer. Rampton (2000) observed partially meltwatermodified till flanking scoured corridors, and beyond corridor margins, thus highlighting the erosional role of variable width meltwater flows, capable of focused incision to produce corridors. Similar morphology has been recognized in other Keewatin

${ }^{1}$ Corridors are mapped adjacent to eskers where scoured bedrock and till (till veneer) mark corridor floors. Their margins are sharp where they truncate drumlinized uplands; they are vague elsewhere as till veneer extends transitionally from corridor floors to well beyond expected corridor margins. Thus, Rampton (2000) found that the formative flows were broader than the entrenched corridors (Fig. 2). 
corridors (Utting et al. 2009; Sharpe et al. 2014, 2017; Campbell et al. 2020; Lewington et al. 2020a). Extensive field-based studies have expanded the inventory of landforms associated with corridors, including various esker elements (fans, splays, and beads; Gorrell and Shaw 1991; Brennand and Sharpe 1993; Brennand 1994; Cummings 2011b), and erosional and (or) depositional hummocks (Utting et al. 2009; Lewington et al. 2020a).

The use of high-resolution terrain models, under the former Scandinavian Ice Sheet, has revealed similar corridor features (Peterson et al. 2017, 2018; Peterson and Johnson 2018), further highlighting the importance of meltwater contribution to a range of intra-corridor landforms (Mäkinen et al. 2017; Peterson et al. 2017, 2018; Peterson and Johnson 2018; Ojala et al. 2019).

Despite this growing body of descriptive corridor morphology and their constituent landforms, few studies have expanded interpretations beyond Rampton's (2000) initial and fundamental conclusions that corridors and their constituent landforms are products of transient subglacial meltwater flow. Lewington et al. (2020a, 2020b) present the most detailed treatment of glaciohydraulic conditions potentially leading to erosion and formation of meltwater corridors. Their approach combines well-established hydraulic theory and observations from modern glacial settings to develop a combined conduit flow-distributed drainage model that explains the occurrence of eskers within meltwater corridors.

The prominence of meltwater corridors speaks to the significance of their formative process(es) for understanding LIS dynamics in western Keewatin. Eskers are often used to infer deglacial processes and patterns (e.g., Brennand 2000; Mäkinen 2003). However, in western Keewatin, meltwater corridors and eskers while distinguishable are not separable (cf. Craig 1964; Rampton 2000; Fig. 1), with as much as $87 \%$ of esker ridges cooccurring with meltwater corridors (Lewington et al. 2020a). Furthermore, the sediment volume eroded from meltwater corridors is as much as 10 times larger than the sediment volume contained within inset eskers (Hardy et al. 2005; Sharpe et al. 2014, 2017; Lewington et al. 2020a). Thus, resolving the glaciohydraulic conditions responsible for corridor-esker formation, and the sediment fluxes associated with these events, is central to understanding deglacial processes and events of western Keewatin.

\section{Study approach and methods}

This study relies on extensive fieldwork carried out during two main helicopter-supported campaigns in 2008-2009 and 2012 (Fig. 1). Six 1:250 000 NTS topographic sheets were mapped and sampled in 2008-2009 in the southwestern portion of the field area near East Arm of Great Slave Lake (GSL). Four additional 1:250 000 topographic sheets were surveyed in 2012. Glacial geology results from 2008-2009, including a photographic inventory (Knight et al. 2017), were published with a focus on regional flow patterns and a mineral resource assessment (Sharpe et al. 2017). During this assessment, observations were noted for striations, s-forms, streamlined landforms, and corridors with inset eskers and transported lithologies. These all demarcate a consistent radiating flow pattern outward from the KID, continuing to the northwest to the Lac de Gras area. Sample site observations of washing, re-working, and truncation of till surfaces further indicated significant meltwater erosion. The similarity in flow pattern between meltwater and ice features implies a response to similar ice sheet gradients, with a single dominant late glacial flow, and the close timing of events. These late deglacial ice flow and meltwater flow features provide important context that bear on our focus on deglaciation processes.

Glacial geology results from the 2012 fieldwork are published in individual government reports (e.g., Knight et al. 2013; Kjarsgaard et al. 2013c; Sharpe et al. 2014). This paper combines and synthesizes all field data from the 2008-2009 and 2012 campaigns with the goal of highlighting the importance of corridor-esker networks to the style and features of deglaciation.

Field data collection methods including mapping, photography, sediment description and sampling in $\sim 659<1 \mathrm{~m}$ pits, pebble and mineral lithology (Kjarsgaard et al. 2014), and measurement of small-scale paleo-flow indicators have been reported by Kjarsgaard et al. (2013b), Knight et al. (2013), Sharpe et al. (2014, 2017), Rampton and Sharpe (2014), and V.N. Rampton and D.R. Sharpe (manuscript in preparation) (additional information in the supplementary file ${ }^{2}$ ). These provenance and characterization studies systematically described the sampled esker, meltwater corridors, and intervening till areas within detailed mapping work. Key sedimentary properties (e.g., texture, compactness, sorting, bedding, clast rounding and concentration) and landforms from these field observations and those in the literature are re-assessed to help define and map corridor, inter-corridor terrain, and ice-marginal features. These observations provided ground verification (Fig. 3) for regional aerial photograph analysis (e.g., Kerr et al. 2013a, 2013b, 2014a, 2014b, 2014c, 2014d) and assessment of LANDSAT, SPOT (Satellite Pour l'Observation de la Terre) panchromatic, and Arctic digital elevation model high-resolution data.

Surficial sediments consist largely of sandy till, localized glaciofluvial deposits, and sparse veneers of glaciolacustrine and littoral deposits. From a synthesis of all data, we compiled a simplified surficial geology map (Fig. 4) where (1) the western portion of the figure is based on Kerr et al. (2014a, 2014b, 2014c, 2014d) and (2) detailed mapping in the northern portion is from Rampton and Sharpe (2014), including 1300 ground observations from Lac de Gras to south of Snap Lake. (3) In the eastern portion of the field area, our field surveys are integrated with air photo mapping of others (Levson et al. 2013; Kerr 2014; Dyke and Kerr 2014; Stea and Kerr 2014; Maynard and Kerr 2014). This regional map highlights the distribution of major surficial materials and outlines patterns of glaciofluvial sediments associated with meltwater corridors and sparse ice-marginal deposits across the study area. This surficial geology map ( 1: 500k) (Fig. 4) does not display the detail behind our analysis (mapping at 1:10-50k scales (see Figs. 5, 6)); however, the principal pattern of east-west meltwater corridors and associated eskers is apparent on more detailed inset maps (Figs. 5, 7, 8, 9) and is illustrated with located field images (Figs. 3, 6). This wealth of data provides a nested-scale understanding of the terrain (e.g., Sharpe et al. 2017) while the ground truth data provide the context for testing deglacial landscape models.

Geographic location of sites and a series of increasingly detailed summary surficial geology maps, which link between landscape observations and a regional network of meltwater corridors are illustrated in Figs. 4, 5, 7, 8, 9.

Additionally, by combining a review of previous field observations with our observations, we are able to assess whether corridors are wider and more complex than currently described using well-defined boundary criteria (e.g., truncated margins). The combined data sets define the characteristics of meltwater corridors, how they formed, and the regional implications regarding style and models of deglaciation.

\section{Observations}

We organize our observations around a two-part division of the most significant landscape components: erosional components (eroded till and bedrock surfaces, meltwater corridors, shore bluffs) and depositional components (eskers ridges and fans, very sparse moraines, kettles, kames). Both components are critical to providing the landform context of interpretations of meltwater corridors and eskers. Observations made around the East Arm of GSL (Kerr et al. 2013a; Sharpe et al. 2017), northward (Rampton and Sharpe 2014), and $\sim 200 \mathrm{~km}$ further to the east (Sharpe et al. 2014) are consistent with previous observations in the western

\footnotetext{
${ }^{2}$ Supplementary data are available with the article at https://doi.org/10.1139/cjes-2020-0136.
} 
Fig. 3. Field images. (a) Corridor (dashed line) truncates drumlin field (d), with terraces (tr) on flanks; note inset esker (E), exposed bedrock $(\mathrm{R})$, glaciofluvial mounds/hummocks $(\mathrm{H})$ and sparse thin till veneer (tv) on corridor floor; $(b)$ thin, eroded till (veneer, tv) with rounded boulders $(\mathrm{R})$ adjacent to scoured bedrock; $(c)$ bedrock with whalebacks (wb) and abundant rounded boulders on eroded surface; note gravel bar in left foreground; $(d)$ coloured aerial photograph $(\sim 1: 20 \mathrm{~K})$ of sculpted corridor margins with scour pits (sp) eroded into till blanket; note esker in small corridor with gravel (light grey tone) across corridor floor; small rounded ponds (black) represent former potholes in meltwater channel network with some where meltwater flow overtopped the incised corridor onto till blanket; (e) esker with narrow, rounded, gravelly sand ridge $(\mathrm{E})$ and wider sandy ridges and fans $(\mathrm{F})$, to the side of the main esker ridge. Scoured bedrock (R) and thin till veneer (tv) are present on corridor floor. Photographs by David Sharpe. Figure 3d from Rampton and Sharpe 2014, fig. 3h.

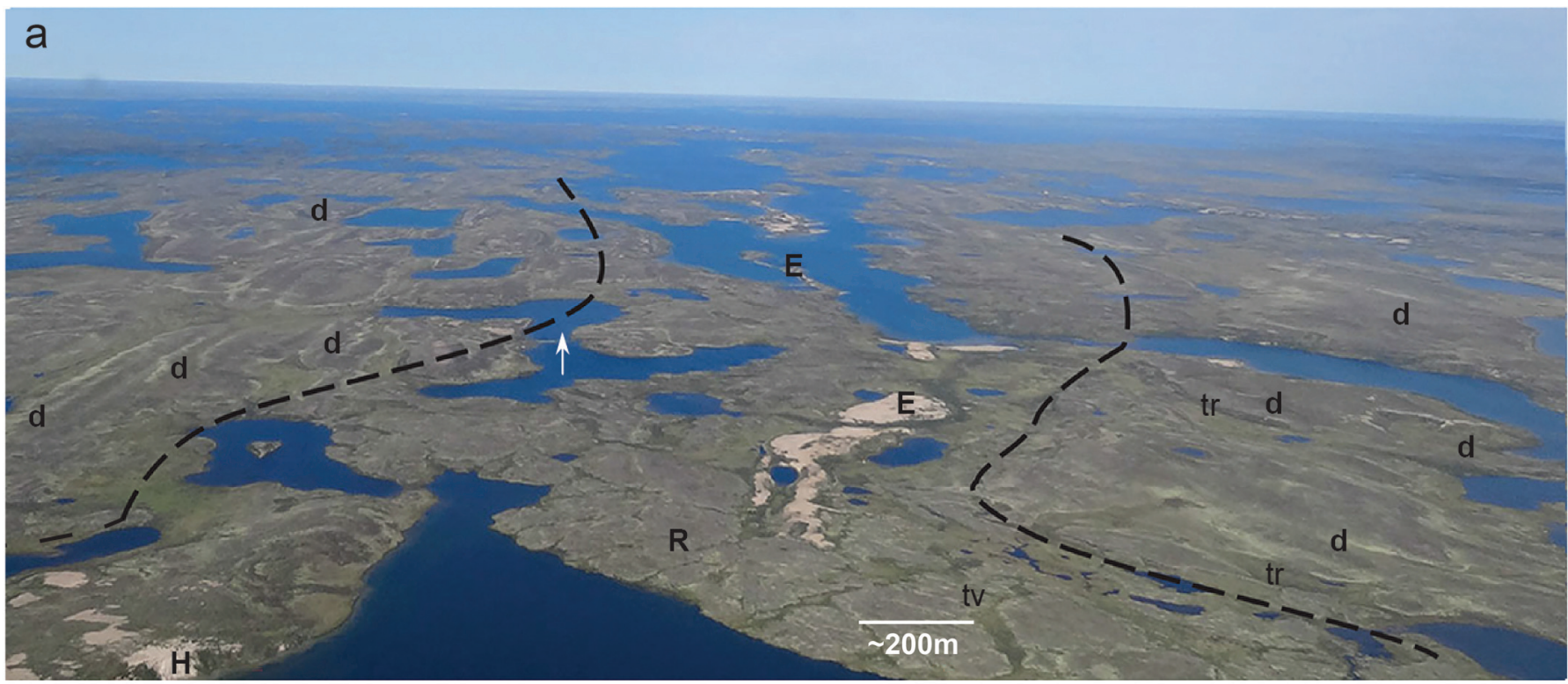

b
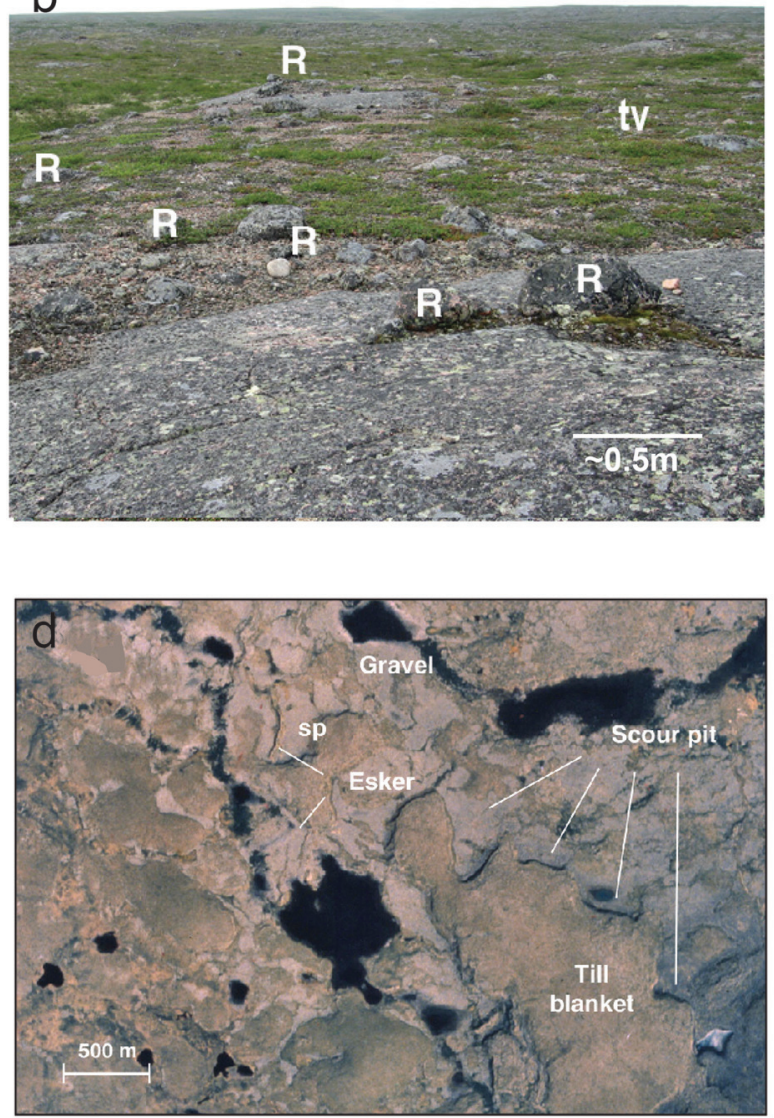

C

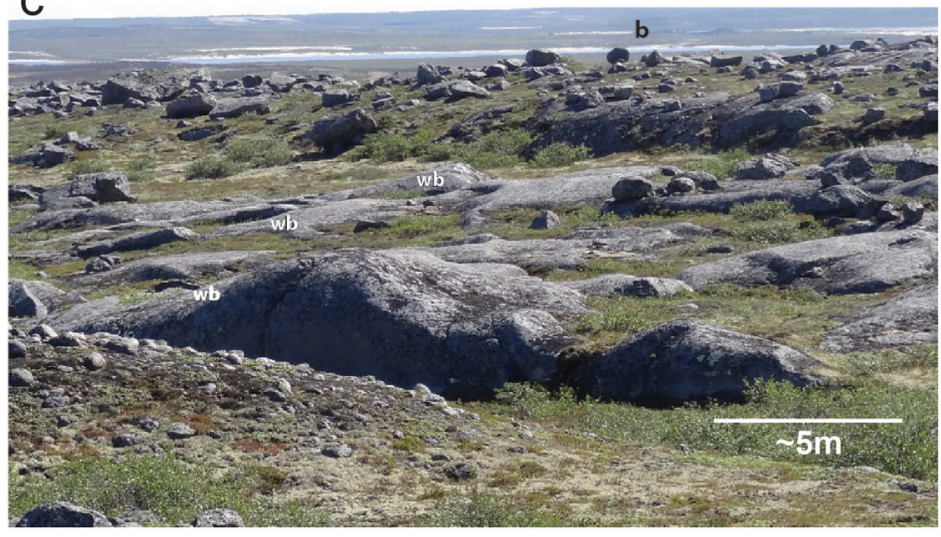

e

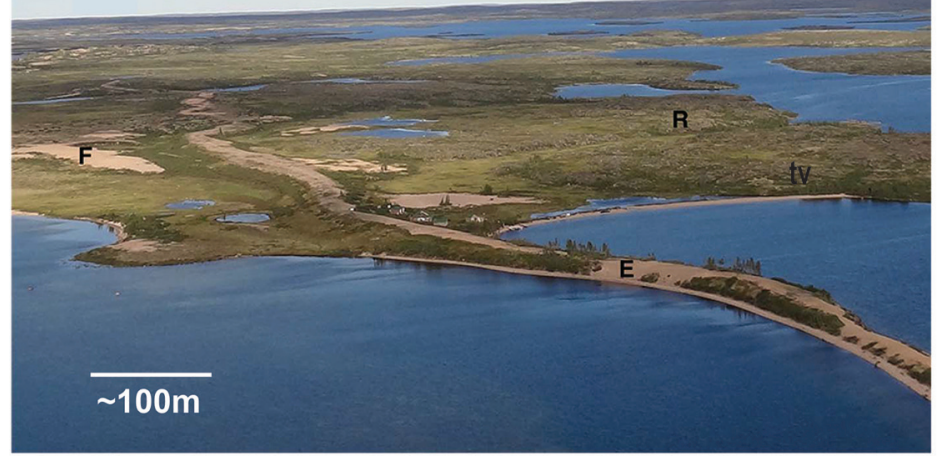


Fig. 4. A series of surficial geology maps (Figs. 4, 5, 7-9) with increasing detail, linked to ground images (Fig. 6), portray a meltwaterscoured landscape comprising truncated till, anabranch channels, corridors, transverse ridges, hummocks and eskers, and sparse moraines. Surficial geology map of the study area is simplified from 11 detailed 1: 125-250 000 maps. Simplified units, bedrock, thick till (blanket, hummocky), thin till (veneer), glaciofluvial and glaciolacustrine sediment (not visible at this scale), provide a framework for meltwater corridors and ice-marginal deposits to be recognize (glaciofluvial sediments) across the map area. Field sites ( 659) are also shown on the map. We co-authored the western portion of the map (Kerr et al. 2014a, 2014b, 2014c, 2014d); others mapped the eastern portion (Levson et al. 2013; Kerr 2014; Dyke and Kerr 2014; Stea and Kerr 2014; Maynard and Kerr 2014), but without the benefit of our field observations. We also co-authored detailed mapping from north of Great Slave Lake to Lac de Gras (Rampton and Sharpe 2014). In the area from Lac de Gras to south of Snap Lake (SL) mapping included $\sim 1300$ field sites and assessment of $\sim 2200$ till samples (V.N. Rampton and D. Sharpe, manuscript in preparation). The figure ( 1: 500 000) does not reveal the detail behind our analysis (mapping at $\sim 1: 5000-50000)$. For example, small areas of hummocky till (3-5 $\mathrm{m}$ ) do not show on the map; however, the map sets the context for the principal pattern of east-west meltwater corridors and related meltwater landforms. Corridors truncate thick till and comprise areas of scoured till veneer and bedrock with inset esker ridges. Note the rare occurrence of ice-marginal landforms (i.e., moraines, marginal channels) at synoptic scales. See Fig. 1 for location context. Geological Survey of Canada maps are used with Natural Resources Canada permission under Open Government Licence - Canada.

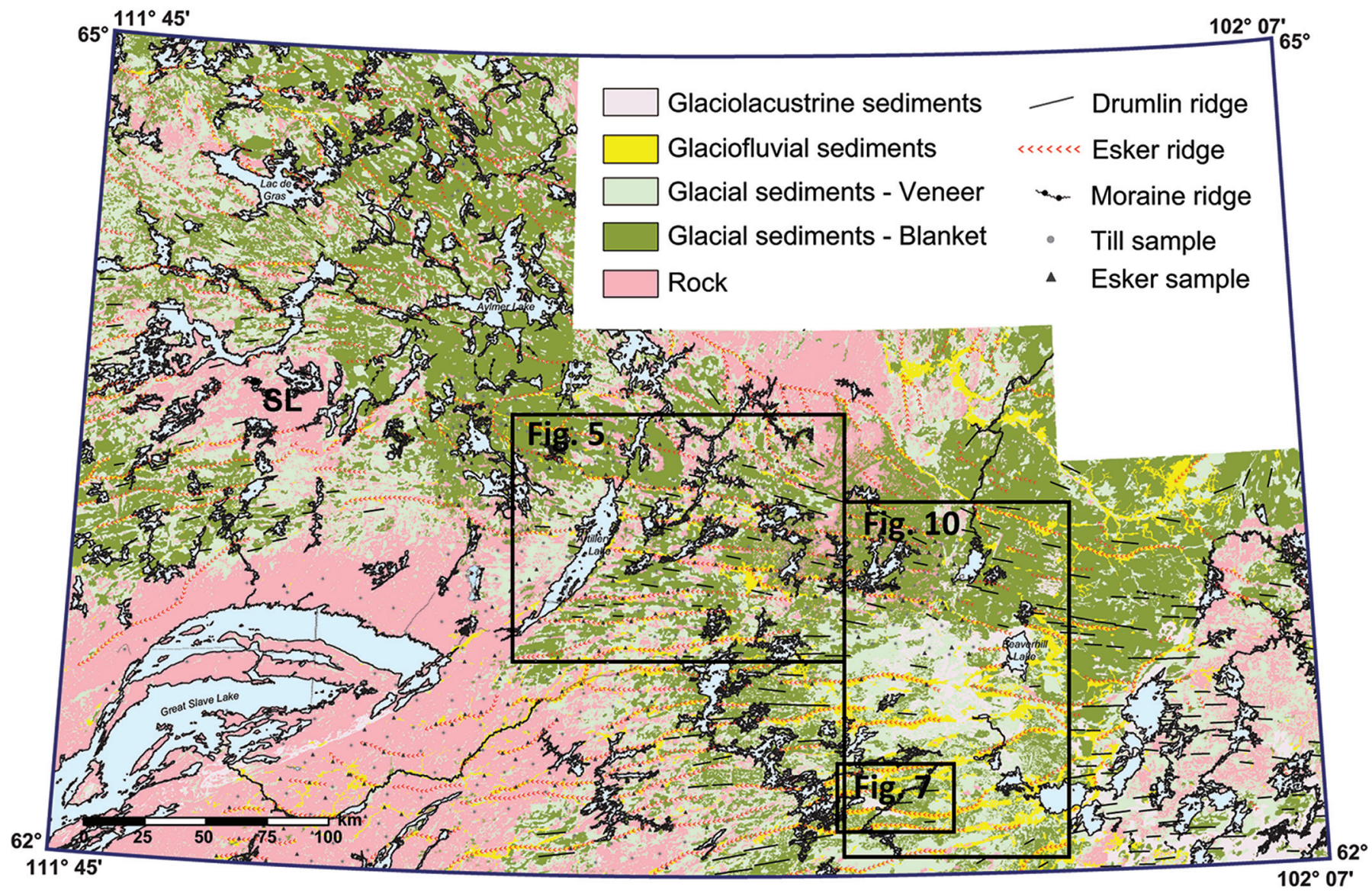

Keewatin (e.g., Craig 1964; Aylsworth and Shilts 1989a, 1989b; Dredge et al.1995; Ward et al.1997; Stokes et al. 2013).

\section{Erosional landforms of Keewatin}

\section{Till and bedrock surfaces}

Sandy diamicton, with limited fines and striated boulders, is the dominant sediment on western Keewatin landscapes and is interpreted as till (Craig 1964; Dredge et al.1995; Kerr et al. 2013a; Sharpe et al. 2014, 2017). It occurs as multi-metre thick blankets and is the main constituent of drumlins across the region. Till is 5-20 m thick in the eastern part of the study area adjacent to the Thelon basin (Fig. 1), but typically thins (1-10 m) further west (adjacent to the East Arm of GSL; Figs. 1, 4, 5). Till also occurs as a thin, $<1 \mathrm{~m}$ thick, discontinuous veneer adjacent to exposed bedrock surfaces (Figs. 5, 6a). This thin till is also transitional from thicker drumlinized till to scoured bedrock surfaces found in corridors (see next section) (Figs. 5, 7). Lateral transitions between drumlinized till (Fig. 6c) and corridor floors can be terraced (Fig. 3a), sculpted, and carry scour pits (Fig. 3d).

Surfaces of till veneer (Fig. 3b) and thick till (Fig. 6b), located primarily within corridors, have localized concentrations ( $<15 \%$ cover) of cobbles and boulders; many are rounded. Sample pits within till surfaces (Fig. 6b) reveal a loose, fines-depleted sand matrix in the upper $0.5 \mathrm{~m}$ of diamicton, with an underlying compact silty sand matrix. Isolated areas of glaciofluvial sediment on till were also observed (Kerr et al. 2013a) as well as blankets (Rampton 2000). Stones are commonly observed ( $2: 1$ concentration ratio) on till surfaces versus pits dug into till where there is no disturbance from frost churning (Sharpe et al. 2014, 2017). Rounded stones (Figs. 3b, $3 c$ ) and sculpted rock erosion forms (s-forms; Fig. 6d; see also Sharpe et al. 2017, figs. $6 a, 6 b, 6 c$ ) are observed on bedrock. S-forms on bedrock, truncated till (till veneer) and boulder accumulations (Figs. 3c, $3 d$ ) also occur on interfluves between corridors. 
Fig. 5. A more detailed (but still simplified) map ( $\sim 50 \mathrm{~km} \times 65 \mathrm{~km})$ shows the key landscape elements (linked to ground images in Fig. 6): thick till (dark green), thin till (veneer; light green), rock (pink), glaciofluvial sediment (yellow), eskers (red), and moraines (black symbols). An anabranch pattern is apparent around the thick till (dark green) and sets apart corridor elements (rock, till veneer, glaciofluvial sediment and eskers) across the landscape. Corridor margins are sharp where they truncate drumlinized uplands; they are vague elsewhere as till veneer (Tv) extends in transition from corridor floors to well beyond corridor margins $(\sim 1-3 \mathrm{~km})$ adjacent to eskers. This broad zone of till veneer and bedrock forms the anabranch pattern with eskers and glaciofluvial sediment set within a better definition of corridor/channels at more detailed scales (Figs. 7-9). This map pattern, with reported ground observations, indicates that the formative flows likely were broad before they broke down to an anabranch system of channels; flow then became entrenched within better-defined corridors close to eskers. Key field sites, M1 to M6, show the details of each mapped terrain unit. (see Figs. 1 and 4 for location context). Derived from Kerr et al. 2013a and used with Natural Resources Canada permission under Open Government Licence Canada.

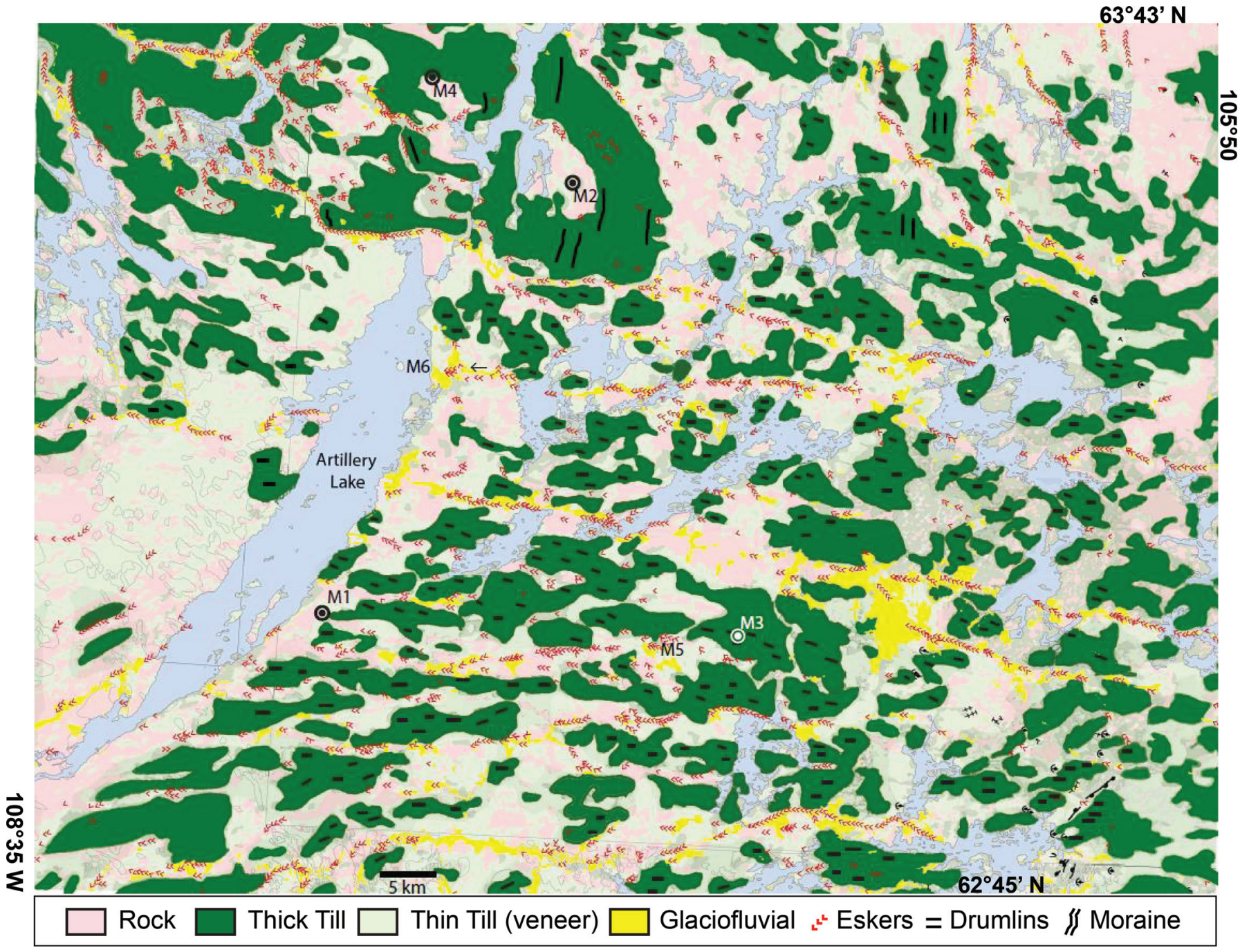

\section{Meltwater corridors, eroded till and bedrock surfaces}

Meltwater corridors (Figs. 4, 5, 7-9) are $1-3 \mathrm{~km}$ wide, $>50 \mathrm{~km}$ long, sediment-poor zones, commonly with inset eskers (Fig. 3a). These corridors have well-defined margins where they are terraced or where they truncate drumlins (Figs. 2, 3a, 3d). These margins may also be diffuse and difficult to distinguish from the surrounding drumlinized landscape (Fig. 7). Corridor floors consist of scoured and sculpted bedrock (many sites have s-forms) (Fig. $3 d$ ), patchy thin till (veneer) (Figs. 3a, 3b), sparse lag boulders on till and bedrock surfaces (Fig. $3 d$ ), and boulder concentrations on some surfaces (Fig. 6e). In addition, corridors in places contain inset hummocks, irregular mounds, and sparse transverse sediment ridges (Fig. 8). The above features are well reported in Keewatin (e.g.,
Wilson 1939; Craig 1964; Dredge et al. 1995; Rampton 2000; Hardy 2005; Utting et al. 2009; Sharpe et al. 2014, 2017; Campbell et al. 2020).

\section{Corridor networks}

Corridors are best mapped based on landform continuity (Figs. 1, 5), corridor pattern (Fig. 7), and in-corridor landforms (Fig. 8), all supported by observations of surface sediment properties. At the scale of the Keewatin sector, corridors and inset eskers exhibit radial regional organization, widening progressively from the former KID toward the glacial margin (Fig. 1). Corridors are typically spaced $\sim 5-15 \mathrm{~km}$ apart, with mapped length continuity of up to $\sim 200-$ $300 \mathrm{~km}$ (Figs. 1, 4, 10), oriented subparallel to ice and meltwater flow 
Fig. 6. Field photographs illustrate the four main map units on Fig. 4 surficial geology map (sites M1 to M6, see Fig. 5): (a) bedrock with till veneer (Tv) and large subrounded boulders (Sr); (b) thick loose sandy till with boulders and little to no exposed rock (M2); (c) thick till with drumlins (d) in background; note light-coloured gravel bar (b) behind the geologist (M3); compare light-coloured gravel bar with white featurehighlighting on aerial photograph (Fig. 9, near site K-70); (d) thin till (veneer) with exposed bedrock, boulders and vegetation; bedrock sculpted by poorly defined s-form furrows (f), lateral trough (n), down flow sculpting (df) and striation (s) (M4); (e) bouldery corridor floor with esker in background; note rounded streamlined bedrock (S) and rounded boulders (R) (M5); and (f) glaciofluvial sediment occurring as esker ridges and fans. This esker complex east of Artillery Lake comprises a flat-topped esker association: esker segments (Fl), sharp-crested connecting ridges (E), and kettles $(\mathrm{k})$; note that fans $(\mathrm{F})$ often occur to the side of the main esker ridge. These elements form a sediment complex (m) perpendicular to the east-west esker trend (E), likely indicating ice-marginal sedimentation, the sole example of this landform system in the map area. Photographs in Figs. $6 a, 6 d, 6 e$, and $6 f$ by David Sharpe; photographs in Figs. $6 b$ and $6 c$ by Ross Knight.
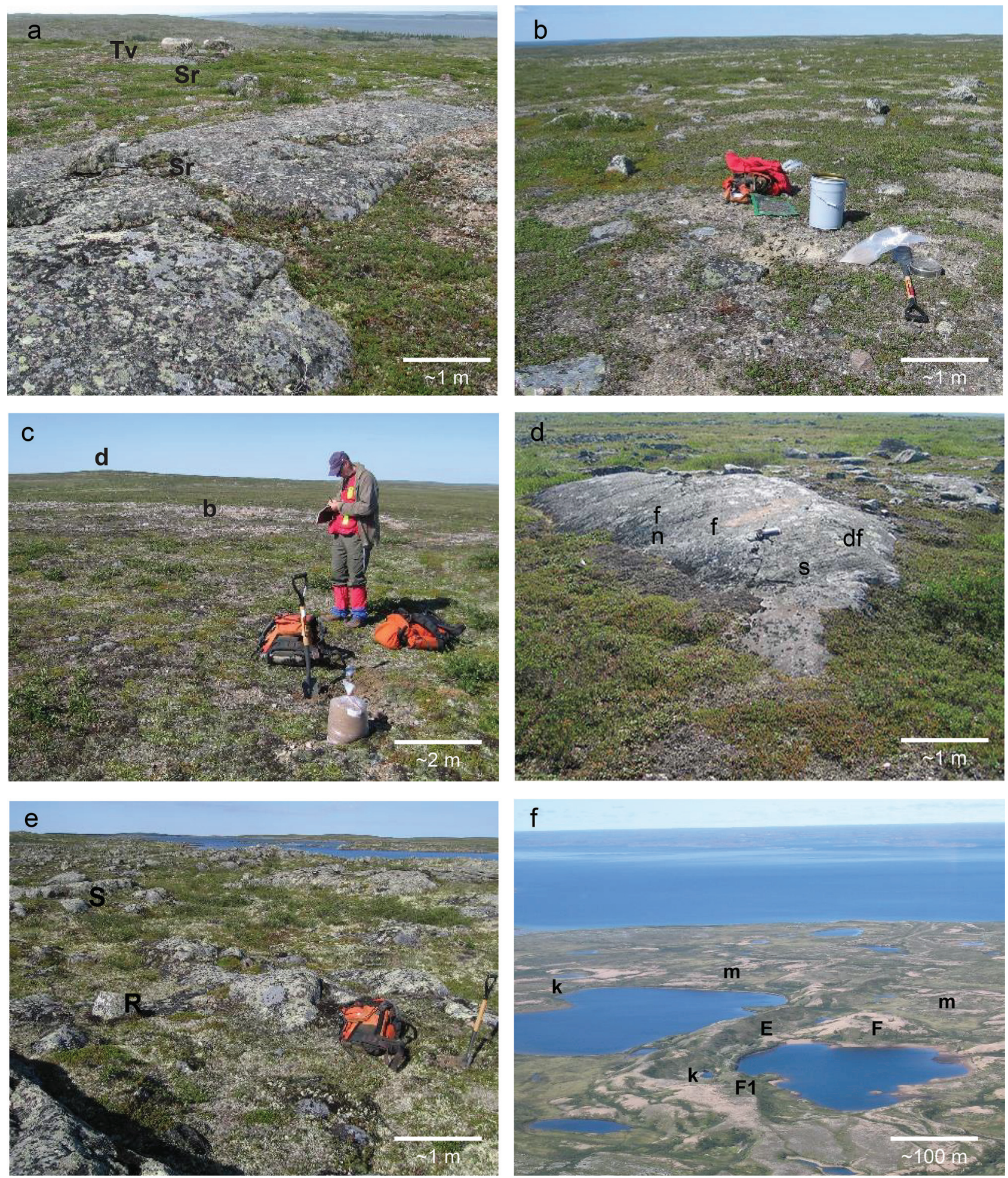
Fig. 7. A SPOT panchromatic image $(\sim 18 \mathrm{~km} \times 25 \mathrm{~km}$ area) shows more detailed mapping ( 1:10 000 scale). Corridors, between drumlin uplands (pink lines) delineated by red polygons, comprise scoured, thin-till erosion zones that truncate and eroded into drumlinized, thick-till uplands. Glaciofluvial sediment (white-blue areas) forms eskers ridges (R), fans (F), and glaciofluvial mounds/hummocks (H) and transverse ridges (T) occur within corridors. Note that fans (F) occur to the sides of esker central ridges (narrow white lines, $\mathrm{R}$ ); moraines are absent and transverse ridges occur within corridors. (See Figs. 1 and 4 for location context.)

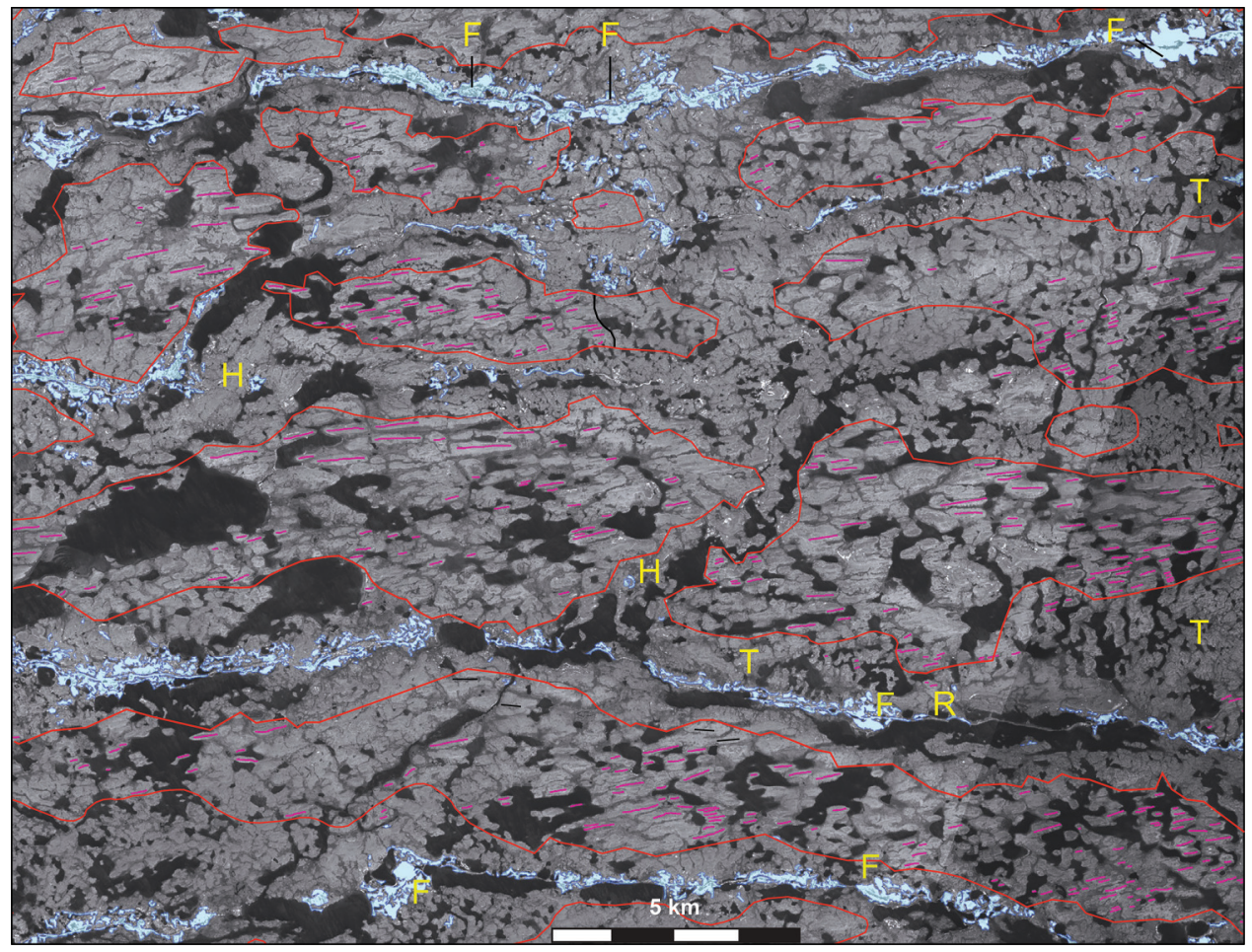

indicators. There is not a strict relationship between corridor width and spacing, particularly where corridor boundaries are vague. Branching patterns emerge when combining surficial materials with corridor geomorphology (Fig. 5). Individual corridors are defined by a dominant incision, but they also bifurcate and form part of an anabranching pattern around groups of drumlins or drumlin uplands (Figs. 5, 7, 8). Field observations further indicate that the surfaces of thick, drumlinized till (Figs. 2, 5) have also been modified to produce concentrations of boulders on the surface (e.g., Site M2 (Figs. 3b, 6b)), and which may indicate meltwater flow external to the corridors. At site M3 (Fig. 5) and site K-70 (Fig. 9), the till surface has a sandy gravel bar on its surface (Fig. 6c), i.e., an eroded, re-worked surface. In the background (Fig. 6c), white lines on the horizon mark a washed, reworked drumlin surface as they are commonly observed on aerial images (Fig. 9). Elongate gravel ridges are observed along the long axis of some low-relief drumlinoids (Kerr et al. 2013b). These gravel bars and ridges are distinct from the rounded cobble ridges (described later) associated with concentric shoreline patterns near the Thelon River.

\section{Interpretations}

We interpret corridors as meltwater erosion pathways that dissected variably thick to thin, till-covered drumlinized uplands. They contain areas of scoured bedrock, eroded till (veneer), till remnants, boulder lags, gravel ridges, and armoured surfaces in and outside of corridors margins (Figs. 3a, 5, 6d) (e.g., Rampton 2000). Eskers within corridors indicate that meltwater erosion likely occurred subglacially. Key landform and sedimentary attributes and associations such as loose, sandy, stony near-surface sediment (Fig. $3 b$ ), terraced drumlins, and truncated and sculpted corridor margins (Figs. 3a, 3d) all indicate that till in the region was originally thicker, and then eroded and reworked by subglacial meltwater, primarily along corridors (Figs. 3a, 5). Corridor erosion was powerful enough to scour sediment and bedrock along focused corridor paths and to remove matrix material to forming loose diamicton, lags and armours in corridors (Fig. 3d), and scour flanking uplands (Figs. $6 c, 6 e$ ). Scour pits on till and s-forms on rock surfaces (Figs. $3 c, 3 d$ ) indicate strong turbulence in the eroding flows. The presence of anabranched meltwater features (e.g., scoured bedrock, till veneer, and boulder lags) beyond corridor margins (Figs. 7, 9) indicates that broader flow preceded channelized corridor flow, as suggested from theory (Shoemaker $1992 b)$, and from empirical data collected from a modern glacier (Flowers et al. 2004). In contrast, by research northwest of our study area, St-Onge (1984) inferred step-by-step corridor formation; however, no resultant ice-marginal sediment wedges were reported. In contrast, Utting et al. (2009) provided sediment observations (10 m of coarsely stratified, matrix-supported, gravelly sand in hummocks) that strongly support high meltwater discharge glaciofluvial formation of corridors $(\sim 120 \mathrm{~km} \times 60 \mathrm{~km})$ and inferences of a broad flow event.

Field observations of the regional pattern of corridors and eskers also supports inferences of subglacial meltwater erosion. Surficial mapping defines the regional pattern of corridors and integrated, anabranching channel patterns (Figs. 5, 7, 8). Intercorridor areas are defined by till-blanket, drumlins, interfluves between corridors where evidence of meltwater erosion occurs, and erosional residuals, as defined by truncated drumlinized uplands, terraced, drumlinized surfaces (Fig. 2), corridor margins, scoured surfaces with clast armours, and lags. These intercorridor observations indicate that flows were initially broad before collapsing to multiple channels, then ultimately entrenching to corridors. Thus, corridor network continuity $(>100 \mathrm{~km})$ and pattern point to regional-scale (i.e., western Keewatin-wide) sediment removal along focused erosional zones. The overall divergent 
Fig. 8. High-resolution digital elevation model (Arctic DEM), of eastern $70 \%$ of Fig. 7 ( $17 \mathrm{~km} \times 18 \mathrm{~km}$ area), further illustrates surface mapped features. The elevation model allows for the identification of corridors (outlined by black lines) with surface roughness, mainly within lower terrain (blue tones), although some corridors rise down flow (east to west) over higher terrain (yellow-red tones) in the west central portion of the image. Roughness on the elevation model relates to transverse ridges (T), hummocks (H), esker ridges (E), and fans (F), as well as scoured depressions (some oriented lakes). Smooth-surfaced higher terrain (mainly yellow-red tones) remains as a residual to the adjacent eroded corridor channels. Residuals are occupied by poorly defined drumlins/drumlinoid features (d), which transition to poorly defined corridor boundaries in places. Note that transverse ridges are glaciofluvial forms within corridors. Distinct lakes in Fig. $8 d$ and in Fig. 7 allow for comparison of terrain features from the Arctic DEM data (Fig. 8) with SPOT panchromatic optical data (Fig. 7). Eskers are better defined in Fig. 7 and corridor features are better defined in Fig. 8. Image courtesy Jeff Harris; created using ARCGIS version 10.8 assembled from the a shaded relief version of the Arctic DEM; interpretation of geology by D. Sharpe.

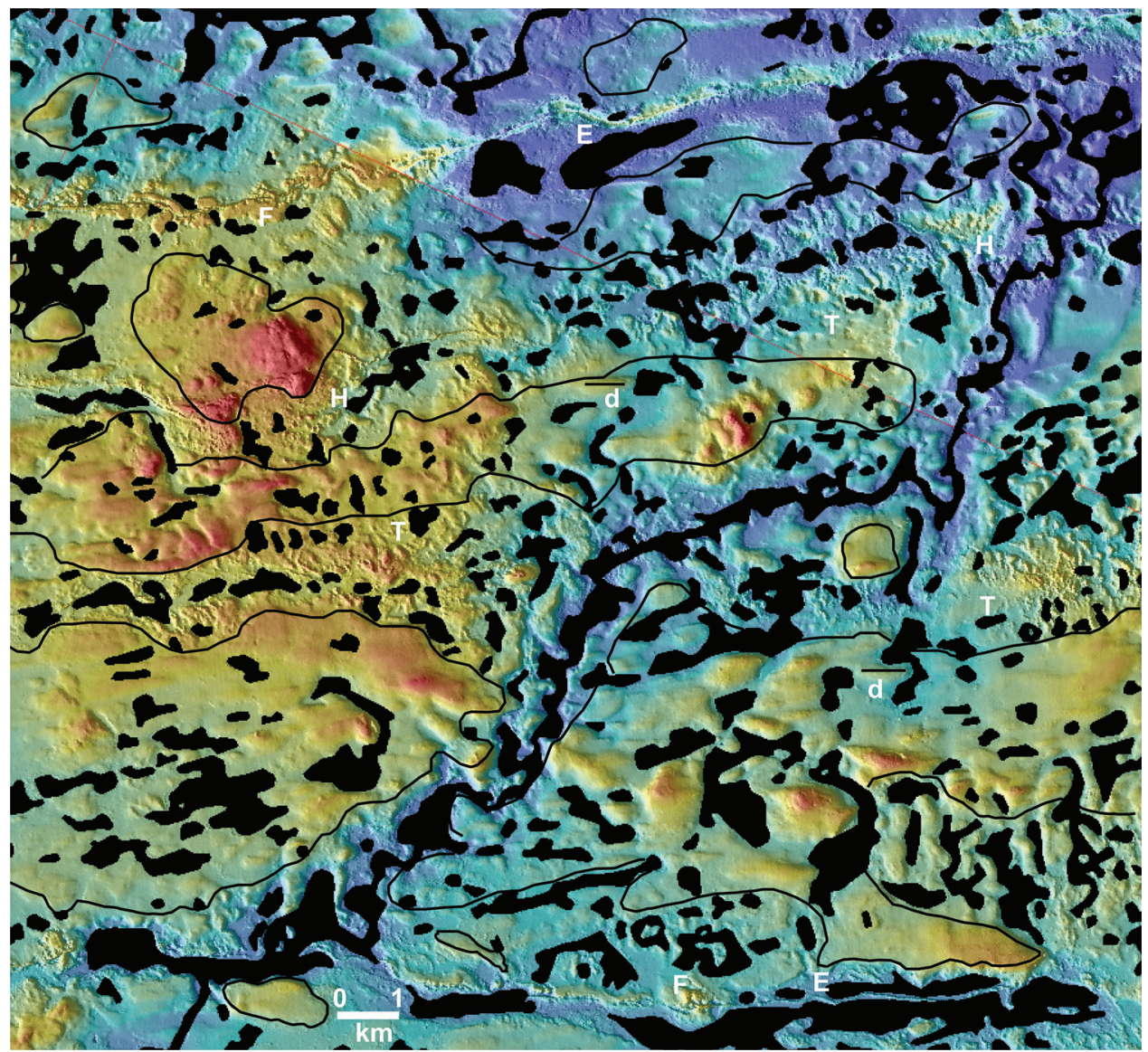

pattern of this network supports interpretation of integrated regional discharge, during a synchronous event (Hardy 2005), as previously suggested for corridors mapped in north-central Keewatin (Rampton 2000; Utting et al. 2009).

\section{Depositional landforms}

\section{Eskers}

A radial array of eskers, inset within corridors (Fig. 1), dominates the western Keewatin portion of the LIS (Prest et al. 1968; Aylsworth and Shilts 1989a; Aylsworth et al. 2012; Storrar et al. 2013). Esker segments are often $\sim 5-25 \mathrm{~km}$ long (Fig. 7); intervening gaps (e.g., Craig 1964), which are common on bedrock highs or within depressions (e.g., lakes), account for $\sim 15 \%$ of total esker length along a corridor pathway. When linking esker segments and gaps, the resulting synoptic picture highlights $\sim 100-400 \mathrm{~km}$ long, regularly spaced, eskers that occur within a regional elongate network of erosional corridors (Fig. 1). Both corridors and inset eskers increase westward in elevation up the regional topographic gradient. Eskers typically consist of two ridge elements (Cummings et al. 2011a): narrow ( 10-25 m), gravelly ridges and wider ( 100-150 m) sandy ridges and fans (Figs. 6f, 3a, 3e). Gravelly esker ridge segments are sharp crested to rounded, 10-30 m high. Sandy ridges are 5-25 $\mathrm{m}$ high and broader than gravelly ridges and, in places, can have sub-segments consisting of flat ridge tops that exhibit rare braided channel patterns (Figs. 6f). Single and multi-crested ridges can transition to low-relief fans within corridors. Sandy fans, up to $1-2 \mathrm{~km}$ wide, extend laterally from one or both flanks of esker ridges (Fig. 3e) or they may be detached from them. Narrow esker centreline ridges run through esker complexes (Fig. 7). Kettles occur in and adjacent to these esker complexes (Fig. 6f), and minor strandline features occur on some esker segments. Hummocky mounds, 3-8 m high and 10$100 \mathrm{~m}$ long, commonly occur in irregular patterns on interfluves between the main eskers set within corridors (Kerr et al. 2013a).

\section{Interpretation}

The large esker arrays, when connected with erosional gaps, form contiguous esker networks similar to concepts outlined by Shilts (1985), Aylsworth and Shilts (1989a), Brennand (1994). This contiguous glaciofluvial network and observed regularly spaced, dendritic pattern (Figs. 1, 10) support the interpretation of esker formation under an integrated regional drainage regime (e.g., Bejan 2000), with westward flow generally up the regional topographic gradient. While rounded and sharp-crested eskers indicate 
Fig. 9. A SPOT panchromatic image of landforms around field station K-70 (site M on Fig. 5, and field image on Fig. $6 c$, shows an area of thick till (T) with drumlins north of this site. To the west lies an area of thin till (veneer, $\mathrm{t}$ ) with exposed bedrock (x), as part of a mapped corridor. Note white highlighting of terrain undulations (thin arrows) that indicate areas of inferred meltwater erosion and washing of the till veneer surfaces (t). Note areas of white highlighting in the thick till (thick arrows), which extend beyond the defined corridor margins (dashed line). Compare this SPOT image with the ground photo at site K070 (Fig. 6c), which has a gravel bar, indicative of meltwater erosion and re-working across both the thick- and thin-till landscapes. Note that this area has little, if any, glaciolacustrine sediment and no known shoreline features (Sharpe et al. 2014) as reported by others (Dyke and Kerr 2014) east of the margin of this study terrain. [Colour online.]

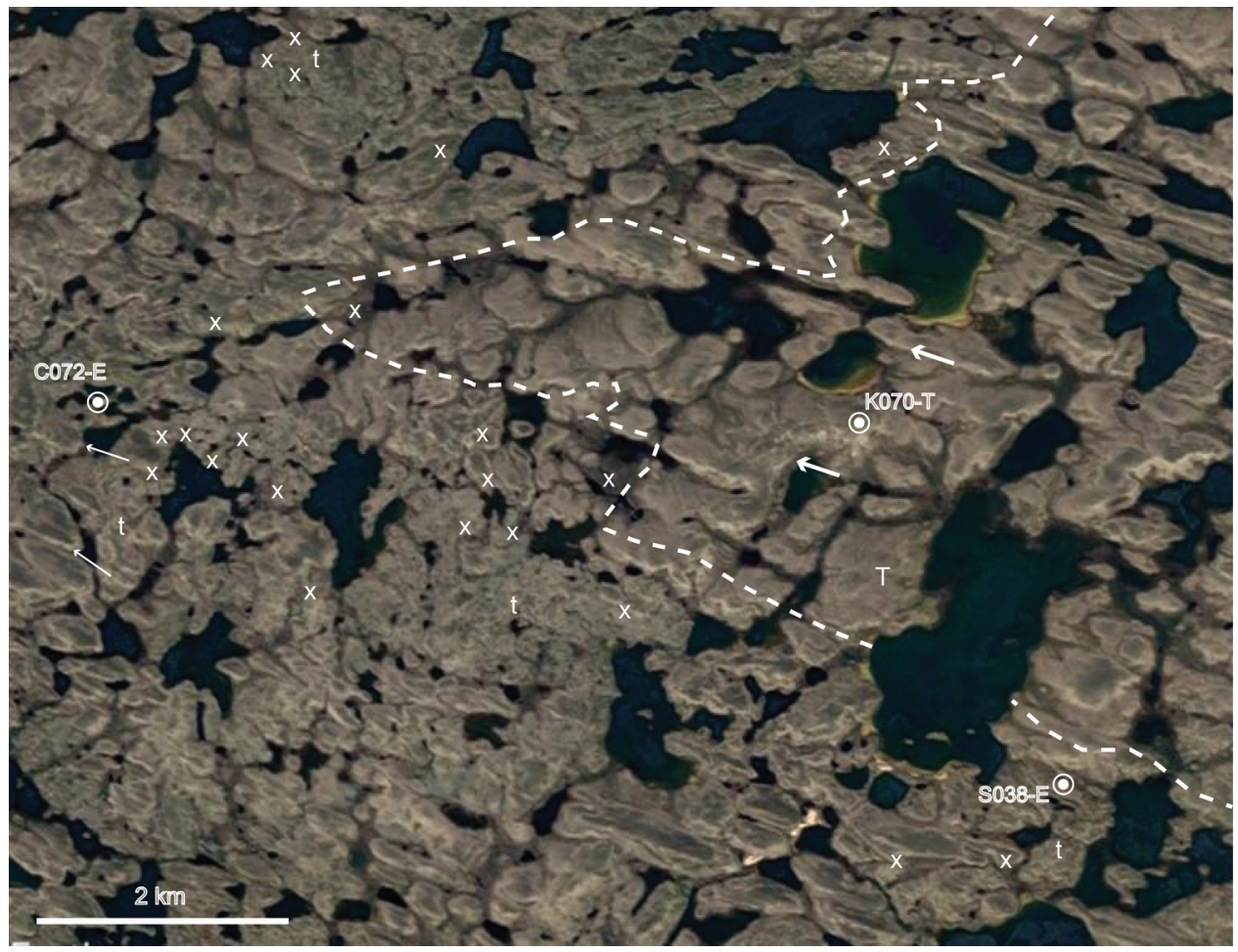

subglacial conduit flow (Brennand 2000; Beaud et al. 2018), the presence of flat-topped esker segments indicates ice-walled flow (i.e., unroofed/open tunnel), or conduit flow at atmospheric pressure (i.e., H-channel, Hooke et al.1990) in thin or stagnant ice conditions (Burke et al. 2012b). Eskers observed within corridors indicates that formation occurred subsequent to (or quasi-contemporaneously with) corridor formation and, most likely, in response to the presence of a pre-existing subglacial meltwater flow path (Brennand and Shaw 1994). Further, the predominance of esker elements adjacent to central esker crest lines (Fig. 3e), as splay/avulsion deposits, supports a model of pre-dominant subglacial sedimentation (Gorrell and Shaw 1991; Brennand 1994). The close association of corridors and eskers could suggest that eskers were formed from the sediments eroded during corridor incision. However, work in the area led Hardy et al. (2005; personal communication, 2009) to estimate that the eroded corridor sediment volume to the deposited esker volume is $\sim 10: 1$. Therefore, the corridor-esker sediment budget implies that an excess flux of sediment likely accompanied corridor erosion and esker deposition.

\section{Ice-marginal landforms}

End moraines and other ice-marginal landforms (e.g., sandar, fans/deltas, shorelines, glaciolacustrine deposits), expected of a retreating ice sheet ${ }^{3}$ (Alley et al. 1997; Stokes and Clark 1999), are sparse to absent in the study area and beyond (Figs. 1, 4, 10; Craig 1964; Aylsworth and Shilts 1989a; Kerr et al. 2013a). Observations reported from extensive drumlin fields across the Keewatin region (Shaw et al. 2010) and in the study area (Fig. 4) have little overlying sediment/landforms, except for disorganized, isolated esker ridges (Fig. 5; Kerr et al. 2013a). North of the KID ( 200-300 km north, northeast of the study area), the McAlpine and Chantrey stratified moraines (Prest et al. 1968) (Fig. 1), comprise stratified sand and gravel of inferred glaciofluvial origin (Aylsworth and Shilts 1989b; McMartin 2017; McMartin and Berman 2015). Although large, these moraines are isolated features, lack continuity, and are volumetrically insignificant when considered in terms of the size of the western and northern Keewatin region. In the study area over an east to west flow extent of $>400 \mathrm{~km}$, there is one observed mappable, transverse to ice flow feature (see site M6, Fig. 5). This north-south-oriented (flow was east-west) $\sim 25 \mathrm{~km}$ long apron of sand and gravel (Fig. 6f), on the eastern shore of Artillery Lake (Kerr et al. 2013b), has been considered to mark a former ice-marginal position (Sharpe et al. 2017). A noticeable set of esker ridges and fans occurs south of Beaverhill Lake (Fig. 10), where a central sharp-crested to flat-topped esker ridge extends through fans that occur only on the side of the central ridge. This glaciofluvial deposit has no equivalents on esker systems north or south of this location (Figs. 4, 5), which could comprise a landform sequence normal to ice flow (e.g., Stokes and Clark 1999). Several isolated till ridges are also mapped as short moraine segments (symbols on Figs. 4, 5), but they show no systematic pattern, nor do they have any considerable north-south elongation normal to east-west ice flow (Figs. 4, 5). Regionally, most eskers do not exhibit pronounced and repeatable patterns of central

${ }^{3}$ Some do not necessarily expect a rapidly retreating ice sheet to leave behind end moraines and other ice-marginal landforms (Stokes et al. 2009). 
Fig. 10. Regional divergent esker pattern, spaced $5-15 \mathrm{~km}$ apart, observed on Google Earth (Image Landsat/Copernicus @2020 Google). Esker ridges (white arrows to light-toned, east-west features) are interspersed with linear gaps (depressions/lakes, G) containing little or no esker sediment. Bounding corridors are not apparent at this scale. BL, Beaverhill Lake; EL, Eyeberry Lake; LL, Lynx Lake; TL, Tyrell Lake. [Colour online.]

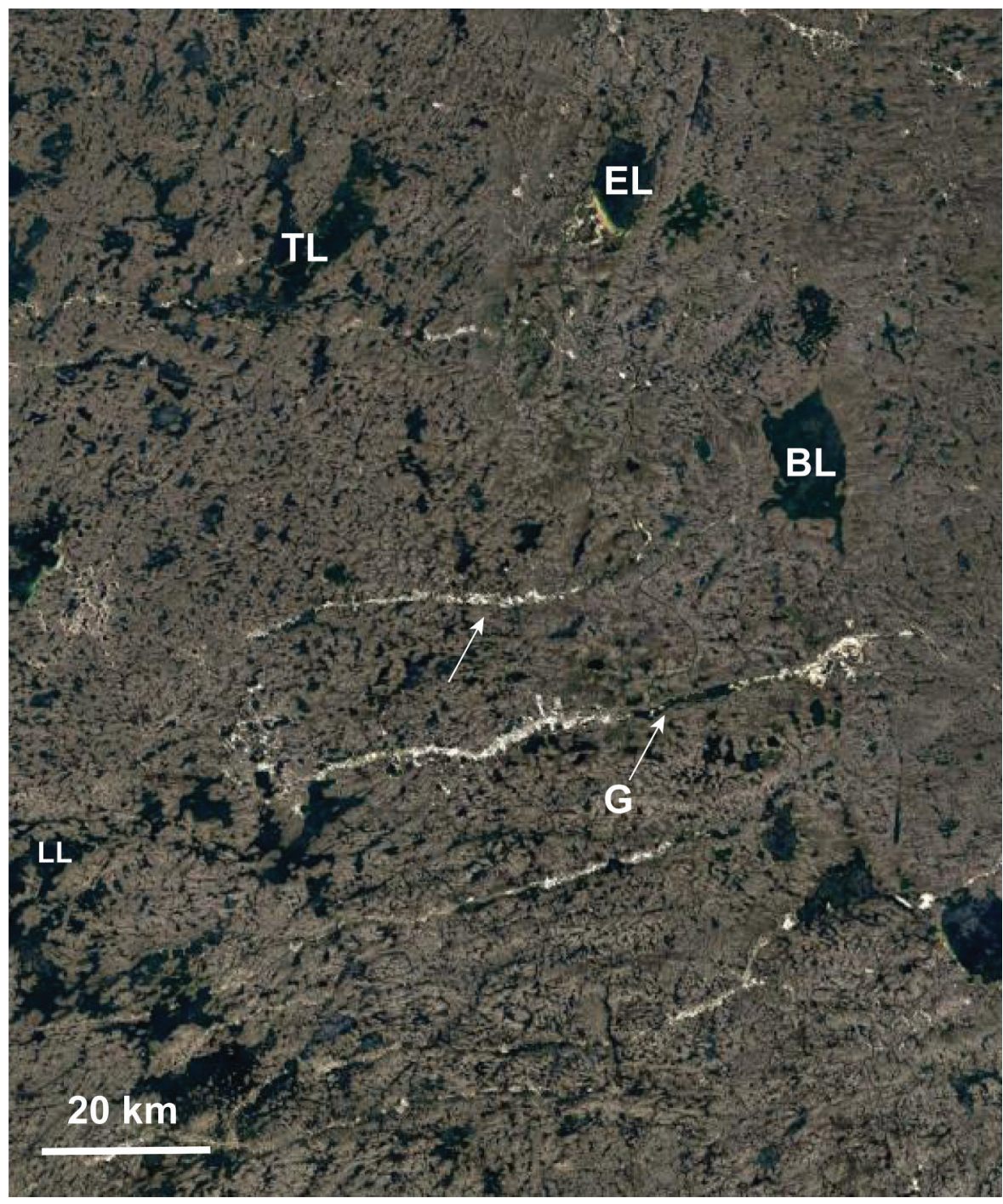

ridges connected normal to fan-like sediment accumulations that could indicate an ice-marginal position (cf. Cummings et al. 2011a) (Fig. 11). Braided outwash plains (e.g., near Artillery Lake) are rare (Fig. 6f; Sharpe et al. 2017), although Craig (1964) mapped a few outwash plains to the north of our study area.

Minor evidence of shoreline development is observed in the form of stepped sediment platforms. Immediately west of Thelon River valley, stepped patterns also overprint till surfaces. Rounded cobble ridges occur near Beaverhill Lake (Fig. 4) yet fine-grained sediment is scarce. An isolated $0.5 \mathrm{~m}$ thick exposure of rhythmically bedded silt-clay (see Kerr et al. 2013c) occurs on the eastern shoreline of GSL and contains $<50$ varve-sets.

\section{Interpretation}

Over the extent of the field area, we observed minimal icemarginal landforms. Moraines such as the Chantrey and McAlpine do not continue southward into our study area, nor do smaller moraines overprint drumlins. Similarly, eskers show no clear evidence of systematic glaciofluvial deposits (e.g., fans) that can be linked in a north-south manner, as could be associated with an ice margin. This is in contrast to expected marginal sedimentation during time transgressive, ice-marginal retreat (e.g., Stokes and Clark 1999; Fig. 4). Our "on-the-ground" observations (Figs. 4, 5) are at odds with past reports (e.g., Craig 1964; Aylsworth and Shilts 1989a). Craig's ice-marginal positions were driven by formative assumptions rather than direct observations. Craig (1964) states that ice-marginal positions were drawn based on (i) ice-flow features (i.e., drumlins ${ }^{4}$ ) formed close to the margin and show the direction of last movement, and (ii) the ice front was at right angles to flow lines. The ice-marginal positions were chosen where the relationship between the ice margin and some significant event in the ice retreat is "known" (Craig 1964). Based on this model, drumlins (tens of metres high), were purportedly deposited close to the

${ }^{4}$ Drumlins, especially large drumlin fields, are now commonly considered to have formed across large areas behind the ice margin (e.g., implied in concepts of flow set (Stokes et al. 2009) and flow tract (Shaw et al. 2010)). 
Fig. 11. Schematic model of terrain elements in western Keewatin region: corridor floor has scoured bedrock (pink), s-forms (s), thin till veneer (Tv), truncated drumlinized till, sculpted bank (SB), gravel lag (dots), terraces (t), stone concentrations (c), hummocks (h), fans $(\mathrm{F})$, transverse ridges $(\mathrm{tr})$, gravel bars $(\mathrm{gb})$, and scour pits $(\mathrm{sp})$, and inset esker. Note that green streamlined ridges in the corridor are transitional to drumlin upland. Flow is from bottom to top (east to west on the landscape) from thicker sediment (Thelon sandstone bedrock lithologies in the east) to thinner sediment in the west (harder Churchill-Slave lithologies). wb, whaleback, see Fig. 3c. Drawing by John Glew.

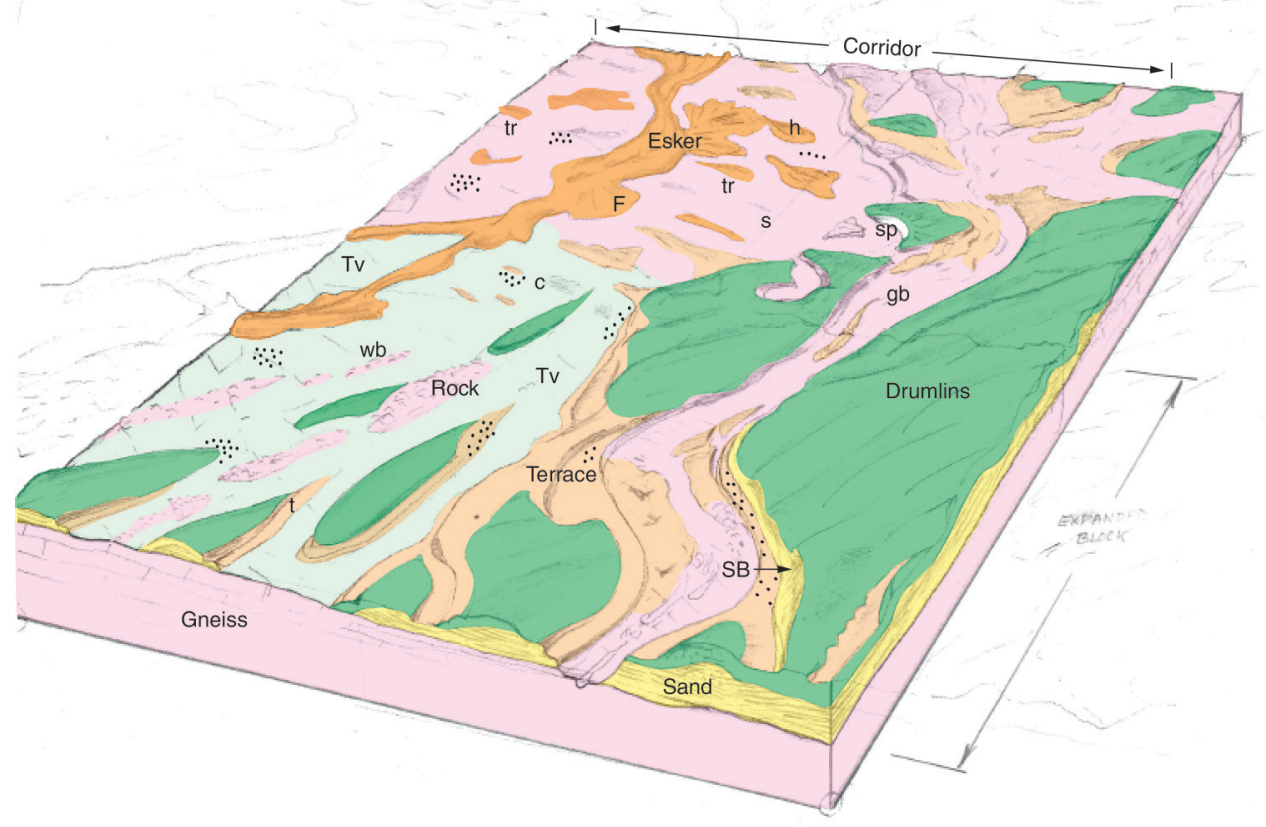

ice margin, but left no other till or sediment ridge as a result. In a modern context, it is unclear how Craig (1964) and later Dyke (2004), who applied similar reasoning, established ice-marginal positions. In contrast, more recent flow-tract or flow-set mapping (Shaw et al. 2010; Stokes et al. 2013) shows large drumlin fields to be continuous and essentially free of sediment cover or marginal till ridges. While Craig (1964) inferred a series of shallow lakes, the lack of fines and short lake duration ( $<50$ varve years) minimizes possible inferences of any significant ice-marginal lacustrine sequences.

Our observations indicate that, in western Keewatin, moraines and other ice-marginal landforms are sparse and most eskerridge fans (Figs. 4, 7) or scattered till ridges cannot be linked to purported ice margins.

\section{Discussion}

\section{Meltwater corridors and formative models}

Meltwater corridors have long been recognized in the western Keewatin region (Wilson 1939; Craig 1964), yet their extent and significance to glacial landscape models, deglacial dynamics (e.g., Dyke 2004), meltwater production (steady-state versus more episodic releases; Utting et al. 2009), and corridor erosional dynamics (erosion of short juxtaposed segments versus continuous erosion over hundreds of kilometres; St-Onge 1984) has been little explored. While there may be significant differences in studied channelized subglacial meltwater systems (e.g., Wingfield 1990; Sjogren et al. 2002; Van der Vegt et al. 2012; Peterson and Johnson 2018), the same basic questions of water source, water flux, and formation length frame the interpretations of eskers and tunnel valleys in other glaciated regions (e.g., Piotrowski 1997; Livingstone and Clark 2016). Based on field data, we consider corridors with inset eskers to be analogous to subglacially eroded tunnel valleys in areas with thick sediment cover throughout glaciated regions of North America and Europe (e.g., Brennand et al. 2006; Kehew et al. 2012).

The paucity of sediment in Keewatin corridors and in icemarginal features helps constrain valley network models (e.g., Cofaigh 1996; Lelandais et al. 2018), with respect to the relative importance of (1) sediment piping (Boulton and Hindmarsh 1987) versus (2) meltwater flow processes (Russell et al. 2007). Tunnel valley formation by piping involves steady-state deformation and movement of sediment by creep into subglacial conduits (e.g., Boulton and Hindmarsh 1987) and by transport of till from the conduit. For our study area, low-energy piping of deformable sediment is too small to account for removal of corridor sediment. Piping is not expected to move sediment far in the subglacial environment, perhaps only to an ice margin. As a result, piped sediments would be expected to form till ridges at icemarginal positions, or, as Livingstone and Clark (2016) argue, tunnel valleys preferentially terminate at moraines (cf. Fisher and Russell 2005). The sediment-piping model does not account for exposed bedrock in corridor segments or corridors incised into bedrock (e.g., Sharpe et al. 2017; Fig. 6c). Furthermore, the presence of s-forms, boulder lags, and armours record turbulent flow, and flow competence far in excess of that expected with piping. Alley et al. (1997) identified ice-marginal sedimentation as forming mainly by glaciofluvial processes. Due to concentrated runoff (mainly subglacial) during deglaciation, stream sediment erosion and transport was primarily due to reworking of existing sediments. Such streams may also rapidly erode sediment from bedrock surfaces (Alley et al. 1997; Beaud et al. 2016) and be significant in transporting and depositing sediment near ice sheet termini.

In Keewatin, the presence of s-forms, scour pits, gravel lags, and glaciofluvial forms (Fig. 11) all suggest high-energy, subglacial meltwater erosion as the key process of corridor formation (e.g., Rampton 2000; Hardy 2005; Burke et al. 2012a, 2012b; Sharpe et al. 2017, Lewington et al. 2020a, 2020b). The tunnel-valley analogy 
Fig. 12. Schematic figure illustrating the accumulation of subglacial water reducing basal friction, leading to a lower profile ice sheet (Shoemaker 1991). Priming of subglacial lakes from drainage of supraglacial water induces lift, ice flow, and ice thinning, all facilitating discharge of subglacial meltwater, enabling sheet flow, anabranched and corridor flow, prior to esker-forming flow. Drawing by John Shaw.

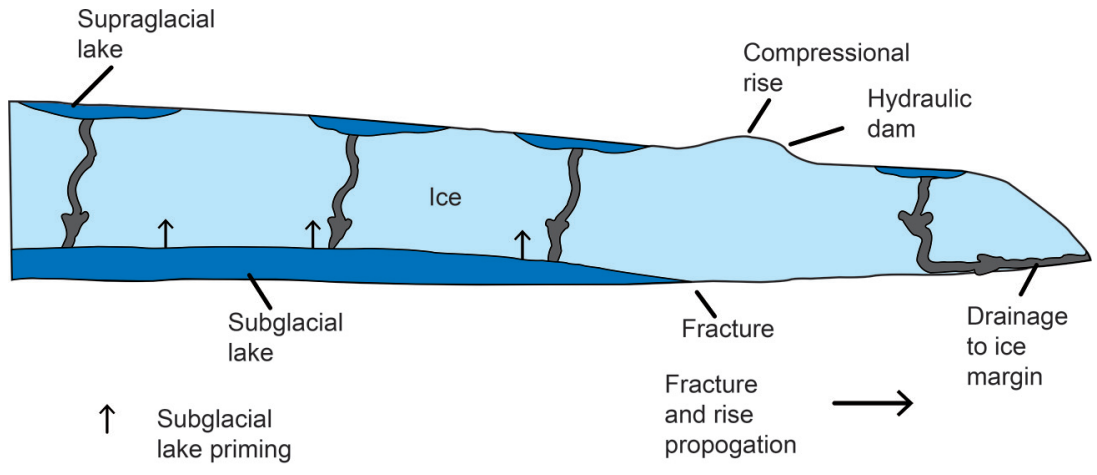

Subglacial Lake Priming

could suggest that corridor-forming events flowed under near-flood conditions (e.g., Cutler et al. 2002), primed by supraglacial to subglacial meltwater water routing (Fig. 12), truncating drumlin surfaces to form terraces, scouring margins and removing most sediment from corridor pathways (Fig. 11). The presence of terraces could also be indicative of longer-lived migration during corridor incision (e.g., Lewington et al. 2020a). The sparseness of terraces in our study area, their narrow form, presence on corridor margins (rather than extending toward the corridor axis), and the occurrence of flat-floored and bedrock-walled corridor segments, all suggest that corridor-forming flows were capable of significant erosion and sediment removal. From our field evidence, we state that corridor flows were sufficiently competent and sustained to scour and sculpt the corridor bedrock floors and to transport all sediments with exception of largest lag boulders. Further, the anabranched pattern dissecting corridor interfluves and margins (Figs. 5, 7, 8) is consistent with corridor-forming flows extending beyond corridor margins, either as broad, sheet flows at the onset of corridor erosion and (or) as flows overtopping corridor margins in response to stage fluctuations (Fig. 13a). Evidence of such broad, collapsing flow, combined with the presence of in-corridor features (e.g., scour zones, s-forms, lag gravel, and modified till; Figs. 2, 6b, 6c, 9) beyond channel margins (Rampton 2000), supports the case that broad flow likely preceded channel formation. This flow eventually collapsed, entrenching corridors and scouring them of most sediment, as predicted from theory shown by Shoemaker $(1992 a, 1992 b)$.

Landforms and processes inferred for Keewatin corridors (Figs. 11, 13) are not unique and may be more widespread across formerly glaciated regions. Concentrated delivery of meltwater (e.g., Utting et al. 2009; Sharpe et al. 2017; Haiblen 2017; Lewington et al. 2020a; and above), as invoked in Keewatin, is also used to explain the formation of meltwater landforms in Scandinavia (e.g., Ojala et al. 2019), where erosional landforms (including small channels) occur in distinct meltwater routes (corridors) containing eskers (Mäkinen et al. 2017; Peterson et al. 2017). These associations of meltwater landforms are indicative of subglacial drainage within large-scale drainage systems on the bed of the former Scandinavian ice sheet in Finland (Mäkinen et al. 2017). The regional drainage system forms a continuum from widely spread, small-scale, distributed subglacial drainage to channelized (esker) flow. These erosional corridors conveyed large discharges of subglacial water under high pressure, prior to flow in large tunnels to form eskers (Ojala et al. 2019). This meltwater sequence is analogous to our inference of sheet flow collapsing to tunnel flow in Keewatin.

\section{Variable pressure model of corridor formation}

New mapping of meltwater features across the Keewatin landscape has led to a consolidation of existing process understanding for corridor formation (Lewington et al. 2020a). This is exemplified by the variable pressure axis model (VPA), first described by Hubbard et al. (1995) and more recently by Lewington et al. (2020a, $2020 b$ ). The VPA model, based on observations of seasonal subglacial water pressure fluctuations in alpine glaciers, involves a central conduit (i.e., R-channel) in which floodwater is forced into the surrounding distributed drainage network.

Here we adopt the general notion of the Lewington et al. (2020a, $2020 b$ ) model, as it builds upon theory and glaciohydraulic concepts introduced by Rampton (2000) and refined through the subsequent recognition of meltwater corridors (Peterson et al. 2017; Sharpe et al. 2017; Ojala 2019). Based on our field evidence, we identify some key conceptual differences focused on the configuration of drainage at the ice-bed interface and the proposed timing of corridor erosion (see "Wider implications for deglacial isochrones and time-transgressive retreat"). Lewington et al. (2020a, p. 28) suggest that "flooding of the broader variable pressure zone is analogous to a narrow sheet flood causing localised flotation or hydraulic lifting" (Brennand 1994; Brennand and Shaw 1994). This is partly misleading as Brennand and Shaw (1994, p. 505) do not mention narrow sheet flows, but specifically provide observations to infer broad sheet flows that covered adjacent drumlinized uplands. From our observations, the complex morphology of corridors and their margins requires that erosional processes (e.g., sheet flow, Brennand and Shaw 1994; Rampton 2000; Fisher and Russell 2005; Lewington et al. $2020 b$ ) initially extended beyond the immediate corridor margin into interfluves - what we describe and map as anabranched interfluves. Subsequent waning flow then collapsed to form corridors, and later, inset eskers (cf. Shaw 1983). This is broadly consistent with the theoretical physics of Shoemaker $(1991,1992 a)$, who showed that sheet flow occurs down flow of subglacial lakes, and tends to become unstable and collapses to tunnel channels. Brennand and Shaw (1994) also observed scour zones and channels on interfluves adjacent to tunnel valleys. A favourable modern analog where excess conduit water pressure leads to transient, sheet-like flow and ice decoupling beyond the conduit margins has been documented during some jökulhlaups in Iceland (Flowers et al. 2004). Here sheet flow occurs during the initial stage of a transient sediment-flushing event and continues until water pressures decrease and conduit flow re-establishes. Significantly, sediment transport seems uninterrupted throughout this event, producing an emergent tunnel valley, an esker segment near the margin, and abundant proglacial sedimentation (Burke et al. 2008). 
Fig. 13. Event sequence for western Keewatin landscape formation in thick till terrain: (a) Eroded landscape due to subglacial meltwater flow, scaled to corridor width with some adjacent bordering upland area, scouring the landscape during sheet flow. The ice sheet may have experienced rapid flow extension and thinning prior to and during this flow event (e.g., Zwally et al. 2002). (b) Corridors are subsequently eroded as meltwater flow down-cut into sediment cover; boulder terraces formed along drumlins and the sides of the meltwater corridors (tunnel channels), during sediment removal. Glaciofluvial erosion features include s-forms, turbulent-flow scours, washed till surfaces, boulder lags, and armours (see terrain details in Figs. 3, 6, and 11). (c) Deposition of scattered glaciofluvial forms (hummocks/sparse transverse ridges) deposited on channel floors prior to ice closure and esker deposition. (d) Ice stagnated regionally: rare moraines (small orange ridges on till upland) and rare marginal esker fans indicate that ice melted down rather than retreating in sequence. Small irregular (esker) mounds (orange) formed on uplands between corridors indicate disorganized drainage compatible with stagnation. Evidence of paleolakes is scarce. Drawing by John Glew.

The VPA process model, as it applies to Keewatin corridors, is not in accord with our field observations. Broad $(\sim 3-10 \mathrm{~km})$ corridors (belts) were observed by Rampton (2000), mapped $>5 \mathrm{~km}$ by Rampton and Sharpe (2014, appendix 1) and 1-4 km, transitional into interfluves, by Campbell et al. (2020), all are wider than features mapped by Lewington et al. (2020a), with a mean width of $0.9 \mathrm{~km}$ ( $3.3 \mathrm{~km}$ maximum width). Broad corridors require erosion wider than a mean width of $\sim 0.9 \mathrm{~km}$, where modified till (Fig. 2) and scour zones and gravel lags (Fig. 6b) were observed on interfluves.

\section{Considerations for regional stagnation}

We revive and expand upon an existing model favouring regional stagnation of a large portion of the Keewatin sector of the LIS (Shilts 1985; Shilts et al. 1987; Aylsworth and Shilts 1989a). This model is more robust for the observed sparse Keewatin ice-marginal features. And, it is consistent with improved understanding of meltwater corridor formation and inset esker networks, and focused on regional ice thinning and stagnation, precluding significant, step-wise, sequential retreat of the ice margin (see Fig. 14).

Within this model, we consider that esker ridges form within R-channels yet their continuity can be difficult to confirm. Clear single-ridged to multi-ridged morphology is consistent with pressurized subglacial conduit flow. Gaps between ridges (Fig. 7), especially scoured bedrock zones, are inferred to record continued conduit flow (e.g., Aylsworth and Shilts 1989a; Brennand 2000). Deposits associated with esker flanks and within corridors (Fig. 7) also are consistent with pressurized conduit flow. For example, esker beads (cf. Gorrell and Shaw 1991; Brennand 1994) are produced by subglacial avulsions (splays of Cummings et al. 2011a) and deposition adjacent to R-channels. Flat-topped, and sometimes braided (Fig. 6f), esker elements likely record unpressurized (i.e., atmospheric pressure) flow conditions in $\mathrm{H}$-channels (Hooke 1984; Beaud et al. 2018) or unroofed former R-channels (Burke et al. 2012a, Perkins et al. 2016) (Fig. 15a). H-channels likely form near ice margins (Hooke 1984), and Beaud et al. (2018) propose that flat-topped esker elements form near the ice sheet terminus and provide an approximate ice margin location. However, an ice margin is not an absolute requirement for unpressurized flow, as this could develop at various locations (Figs. 15a, 15b) along a decaying and regionally, low-profile, stagnating ice sheet where R-channel, H-channels, and unroofed H- or R-channels form a continuum toward unpressurized conduit flow. In a stagnating ice sheet, surface slopes could have a decreasing influence on hydraulic gradients with respect to bed topography. Supraglacial

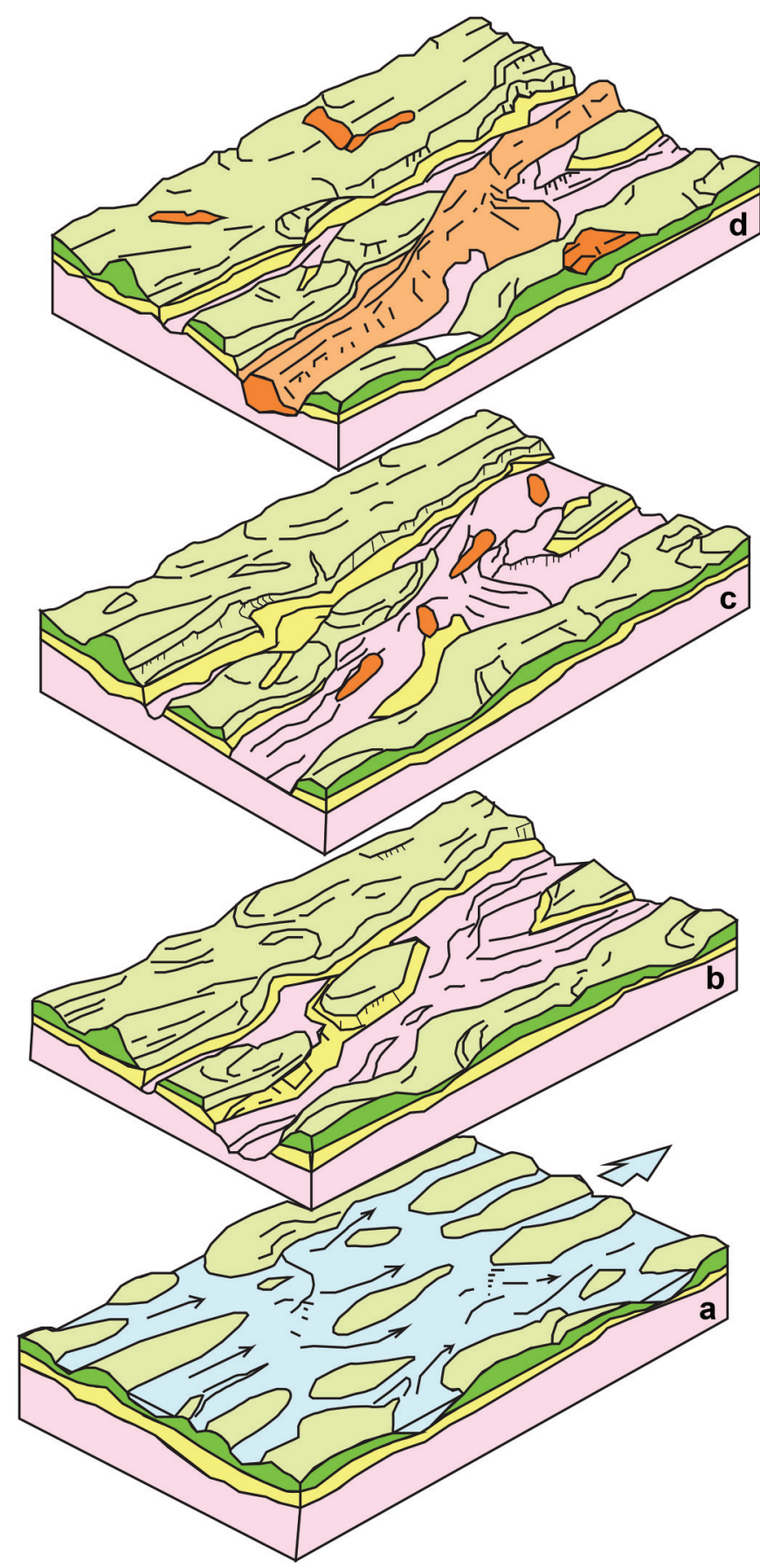

ponding and drainage to the glacier bed (Fig. 12) could provide the necessary hydraulic head for conduit flow (Brennand 2000). The close association between corridors and eskers indicates that, even during decay, corridors provided a local hydraulic sink for esker formation. In addition, esker and corridor elements, such as sediment mounds/hummocks and lateral esker fans, are consistent with localized surface-to-bed meltwater drainage. Kettles flanking eskers also reflect decay and stagnation of collapsed ice blocks trapped in sediments moved by low-energy flows associated with esker fans along corridors and conduits. Furthermore, the presence of scattered glaciofluvial ridges (kames, e.g., Kerr et al. 2013a) on corridor interfluves and between main esker paths, likely relate to disorganized drainage and local deposition under stagnating ice. In addition, outwash zones, inferred by Craig (1964), may relate to a 
transition zone between active and stagnant ice (Fig. 15a). Shoreline features ornamenting some esker segments are consistent with local water ponding in unroofed R-channels. An implication of our regional stagnation model is that some esker elements (flat-topped, braided segments, mounds, kettles, deltas, and fans) might be latestage features, post-dating the formation of main esker ridges (Fig. 15b), and largely ornamenting an existing esker core structure formed in pressurized R-channel conduits, all set within a long, pre-existing corridor.

Aylsworth and Shilts (1989a) used the integrated regional pattern of eskers and steep-angled junctions between trunk and tributary eskers to argue for decaying to dead-ice conditions controlling low-profile, hydraulic gradients between tributary and trunk eskers. Widespread stagnation was also inferred by preservation of ribbed/Rögen moraines/Rögen terrain (Aylsworth and Shilts 1989a, 1989b; Bouchard 1989; Stokes and Clark 2003), yet this interpretation remains equivocal (e.g., Shaw 2002; Clark 2010). These propositions of regional ice sheet stagnation imply that the ice sheet thickness was regionally reduced (Clark et al. 2000 inferred a $400 \mathrm{~km}$ wide ablation zone in the Labrador Ice Sheet), by surging (Shilts 1985), ice streaming (Stokes and Clark 2003), and (or) flooding (Kamb 1985; Shoemaker 1992a).

\section{Low-profile ice sheets and drainage events}

Our proposed event sequence of corridor and esker formation (Fig. 13) incorporates processes capable of reducing ice sheet thickness and deglaciation through stagnation. Shoemaker (1991, $1992 a, 1992 b)$ demonstrated the importance of subglacial water storage (reduced bed shear stress) and release to the flattening of ice sheet surfaces, a phenomenon since observed in modern ice sheets (e.g., Zwally et al. 2002; Bartholomew et al. 2010; Dow et al. 2015). Specifically, he argued that supraglacial and subglacial water storage were possible on, and under, large lowland ice sheets, and that broad sheet flows were likely outcomes of this storage. This resulted in decoupling of the ice from its bed over a thickness of many metres, similar in scale to decoupling observed during some Icelandic jökulhlaups (Russell et al. 2007; Flowers et al. 2004).

The numerical predictions of Shoemaker $(1992 a, 1992 b)$ converge with our own process reconstructions from Keewatin landscapes. Specifically, the inference of broad, sheet-like flows $(\sim 10 \mathrm{~km}$ wide and wider in the broadest anabranched interfluves) in the early stages of meltwater corridor incision (Fig. 13) is supported by the observed anabranching pattern of dissected till residuals (Figs. 5, 7, 8, 9). The minimum width of sheet flow in Keewatin is estimated where meltwater erosion features (s-forms, till truncation, veneer, and boulder lags; Fig. 3) occur on uplands between corridors, extending $>1-5 \mathrm{~km}$ beyond defined corridor boundaries to cover at least $50 \%$ of inter-corridor area (Fig. 9). While the scale of sheet flow may be restricted to corridor margins as suggested by Kehew et al. (2012), flow for the wider corridor network may have resulted in lifting and enhanced ice flow along portions of the ice sheet (Alley et al. 2006; Lelandais et al. 2018). Enhanced meltwater-glacier flow on the scale of the Keewatin corridor network may have similarly decoupled the ice sheet, making it susceptible to stretching and thinning, leading to possible reductions in mass, surface gradients, and limiting marginal oscillations (Alley et al. 2006), thus pre-conditioning for stagnation and hastening the pace of deglaciation as proposed by Shoemaker (1992a).

\section{Rapid retreat: an alternative deglacial model and compatibility with regional stagnation}

Deglaciation by "rapid retreat" has been proposed for portions of the Canadian Arctic (Stokes et al. 2009) including being invoked by Lewington et al. (2020b) as part of step-wise retreat in western Keewatin. Rapid retreat (Clark et al. 2000), or recession at rates $>50 \mathrm{~m}$ to $\sim 300 \mathrm{~m} /$ year (e.g., Stokes et al. 2009), may be a viable option for explaining the sparseness of ice-marginal landforms in western Keewatin. Where it has been proposed, rapid retreat follows ice stream shutdown events, and a thinned portion of the ice sheet (due to ice streaming) rapidly exposes the glacier bed without leaving a substantial ice-marginal record. This mechanism has been invoked dominantly for de-stabilized, marine-terminating ice streams (Stokes et al. 2009).

Three key points weaken the applicability of this model in western Keewatin. First, no paleo-ice stream has been identified in the study region. Although drumlins are present, their organization does not match the predicted "footprint" of an ice stream, as inferred near Dubawnt Lake (Stokes and Clark 1999, 2003). Second, corridors and eskers require substantial meltwater to form and, if ice sheet thinning is required to condition rapid retreat, then this would greatly limit the meltwater volumes available for corridor and esker formation. Third, Lewington et al. (2020a) envisage co-development of corridors and eskers, and recognize that the eroded corridor volumes exceed esker volumes $\sim 10$-fold. Although rapid retreat may account for sparse recessional moraines, it cannot, at the same time be invoked to explain the absence of ice-marginal glaciofluvial sediments, given the eroded volume of corridors.

We suggest that the "rapid retreat" model is fundamentally a model of "rapid and near-contemporaneous glacier bed exposure" that does not uniquely require rapid ice retreat. In absence of ice streams and a marine terminus in western Keewatin, we conclude that the evidence predicted by an "active retreat" model can be equally well explained by a process of ice sheet stagnation where a broad stagnating zone dominantly melts down (with subordinate melt back) to expose its bed more or less contemporaneously. The paucity of down-wasting ice features may be due to the low relief of Keewatin terrain where glacial flow was extensional, with little compressive flow to move sediment higher in the glacier snout. This is in contrast to the classic stagnation model (e.g., Clayton and Moran 1974) of widespread downwasting leading to a disorganised landscape of englacial and supraglacial debris melt out.

\section{Wider implications for deglacial isochrones and time-transgressive retreat}

\section{Eskers: implications for understanding deglaciation of the western Keewatin sector of the LIS}

The step-wise landform pattern implied within the ice retreat chronology of Dyke and Dredge (1989) identifies eskers as having formed in a time-transgressive sequence (Dyke 2004), a premise that requires testing.

Deglacial processes inferred from Keewatin eskers within morphogenetic schemes relate to length and continuity of channels responsible for esker formation. The "short conduit" model, where conduit length is scaled to the ablation zone, emphasizes step-wise retreat of the active ice margin and juxtaposition of short conduits/esker segments, i.e., significantly shorter than the total length of an esker as visible on the landscape (cf. Cummings et al. 2011a and references within) (Fig. 14). Water supply to such conduits can include steady-state meltwater production (surface and basal melt) (Fig. 14), more transient larger magnitude meltwater delivery (Burke et al. 2012b; Russell et al. 2006), and drainage of supraglacial lakes and (or) subglacial reservoirs (Fig. 12). In contrast, the "long-conduit" model that has been associated with ice sheet stagnation (Brennand and Shaw 1994) proposes that total esker length approaches total conduit length (Shreve 1985) (Fig. 15). The distinction between these two end-member scenarios, and any deglacial inference, hinges upon the ability to confidently identify former ice margins either directly (e.g., mapped moraine ridges) or indirectly through proxy landforms associated with esker element morphogenetics and sediment flux (cf. Brennand 1994; Burke et al. 2012b; Perkins et al. 2016; Beaud 
Fig. 14. (a) Schematic pattern of active step-wise ice sheet retreat. Meltwater routing includes supraglacial streams and moulins connecting to subglacial conduits (R-channels) debouching as proglacial streams. This pattern is expected to repeat itself over time $\left(t_{1}, t_{2}, t_{3}\right)$ as the margin retreats (e.g., Stokes and Clark 1999, fig. 4). (b) Expected landform and sediment record resulting from the step-wise, active retreat pattern in Fig. 14a). Subglacially eroded and transported sediments build ice-marginal glaciofluvial fans and outwash plains (e.g., Marren 2005). Step-wise retreat implies that the depositional land system repeats itself at successive ice margin positions marked by contiguous or near-contiguous terminal or recessional moraines that are perpendicular to ice flow. Drawings by Jerome Lesemann.

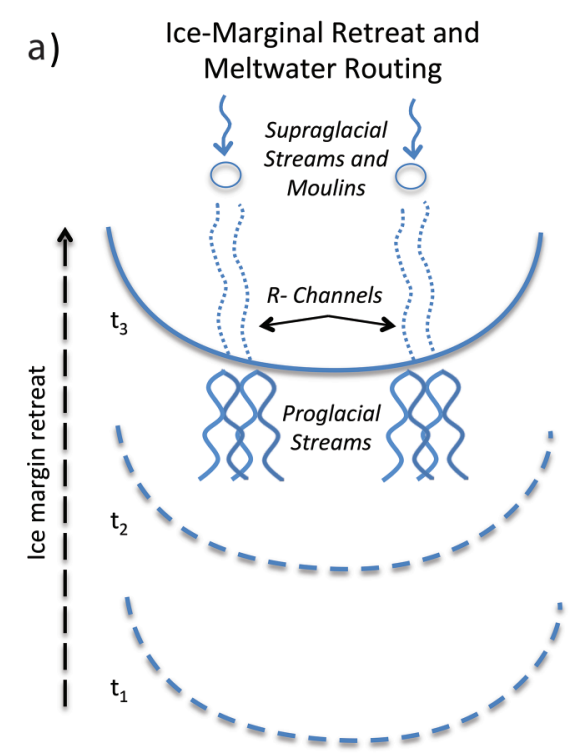

et al. 2018). For example, sharp-crested, rounded esker elements in western Keewatin likely relate to reservoir drainage events (Perkins et al. 2016).

\section{Inferences of deglaciation patterns conditioned by reconstructed isochrones}

The pattern and timing of LIS retreat was summarized by Dyke and Prest (1987b), updated by Dyke (2004), and recently discussed by Dalton et al. (2020). These authors present reconstructed ice margins locally supported by landform mapping (below marine limit) and a variable geographic distribution of dates to constrain the timing of ice sheet retreat. Using a series of maps, these data were used to create a step-wise retreat pattern, as each sketched ice margin is fixed and associated with an isochrone. The stepwise retreat pattern was reinforced by Dyke and Dredge (1989, p. 210) and relies on the assumption that "ice-flow features, and associated meltwater features such as eskers, were formed in a time-transgressive sequence, forming later the further inward during deglaciation” (Dyke 2004, p. 372).

Our study area lies within a region where Dyke (2004, p. 374) cautioned that incomplete landform coverage and limited "opportunities to directly date ice-marginal features, landward of the limit of postglacial marine incursion, are exceedingly rare", resulting in isochron uncertainty. Consequently, western Keewatin isochrones rely on the assumption that where ice margins are not recorded by mappable features, these margins trended (were drawn) normal to ice flow directions (Dyke 2004, pp. 371-372), a strategy adopted from Craig (1964). The uncertainties associated with these isochrones have been largely disregarded as the purported ice margins (and the implied step-wise ice margin retreat) are implicitly accepted in some synoptic reconstructions of LIS dynamics. This includes the relative timing of formation (e.g., $~ 50-200$ year isochrones) of some landform sets (e.g., eskers, Storrar et al. 2013, 2014a, 2014b; ice streams, Margold et al. 2018), and calibration of

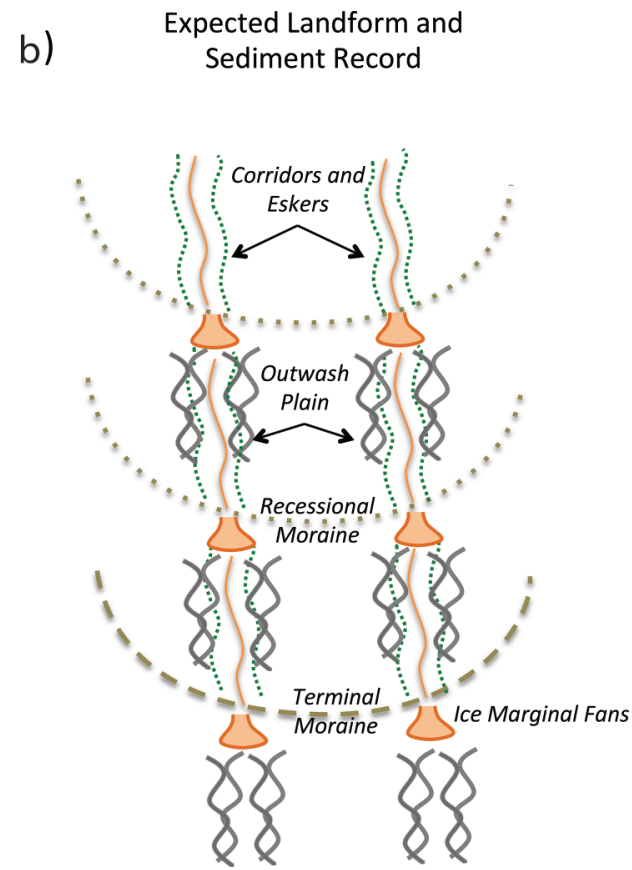

numerical ice sheet models of the LIS (Tarasov and Peltier 2004; Tarasov et al. 2012). More recently, Lewington et al. (2020a) use the purported ice margins and isochrones interchangeably to calculate retreat rates and to estimate relative rates of meltwater production. Recent updates to the compilation of deglacial chronologies (Dalton et al. 2020) shed little additional light on western Keewatin as no new dates quantify isochrones nor help establish ice margin retreat.

It remains unclear whether the scattered dates available across Keewatin terrain (Dyke et al. 2003; Dalton et al. 2020) provide clarity on Keewatin deglacial style and chronology. Keewatin terrestrial dates span ca. $12.7 \mathrm{ka} \mathrm{BP}$ (west of GSL) to ca. $5.55 \mathrm{ka} \mathrm{BP}$ (near Dubawnt Lake just west of the KID, Fig. 1). This broad westto-east pattern of declining ages shows regional asymmetry that could suggest a pattern of sequential ice retreat rather than regional stagnation. Careful review of a sample of sparse Keewatin dates, for example a small cluster of dates $\sim 100 \mathrm{~km}$ north of GSL, shows a range from 6.15 to $7.71 \mathrm{ka}$ (Dalton et al. 2020). This wide age cluster lessens confidence of a credible chronology in support of sequential ice-marginal retreat. Eastward from the GSL cluster and extending $\sim 400 \mathrm{~km}$ to the Dubawnt Lake dated site ( $\sim 5.55 \mathrm{ka})$, there are no dates to draw reliable isochrones across our study area. While dates $\sim 400 \mathrm{~km}$ to the north (all marine dates, $>7.74 \mathrm{ka}$, with landforms), and south of $60^{\circ}$ north, may allow for isochrone delineation, these examples indicate that the Keewatin chronology is not well constrained, certainly not to $\sim 100$ year isochrone resolution as applied by some (Lewington et al. 2020b).

We earlier downplayed the possibility of rapid ice-marginal retreat ("Rapid retreat: an alternative deglacial model and compatibility with regional stagnation"). This model, or a variation of it that does not rely as much on ice streams to condition retreat, may help reconcile the apparent discrepancies between the paucity of ice-marginal landforms and the sparse dates across western 
Fig. 15. (a) Schematic pattern of regionally stagnant ice sheet, including a zone of stagnation connected to a zone of thicker active ice. Meltwater routing in the active zone resembles that depicted in Fig. 14a. In the stagnant ice zone, local surface melting routes irregularly in response to the uneven decaying ice sheet surface. Depending on routing and ice thickness, conduit flow can occur in pressurized conduits (R-channels), in atmospheric pressure conduits (H-channels) and in open ice-walled conduits formed from unroofed R- and H-channels. Local ponding can occur along conduit segments. Some surface melt and conduit flow supply proglacial streams. (b) Expected landform and sediment record resulting from regional stagnation. Single-ridge and multi-ridge eskers result from R-channel flow. Flat-topped segments form from H-channel and open channel/unroofed R-channel flow and ornament existing esker ridges. Esker fans within corridors, sediment mounds, and kettles result from late-stage water flow and conduit collapse, respectively. Eroded sediments along conduits and eskers may build outwash plains and ice-marginal fans. The model accommodates small deglacial lakes that have been inferred in parts of Keewatin (e.g., Campbell et al. 2016, 2019). No systematic repetition of this land system is required or expected due to the absence of a sequential, actively retreating margin. Drawings by Jerome Lesemann.

a)

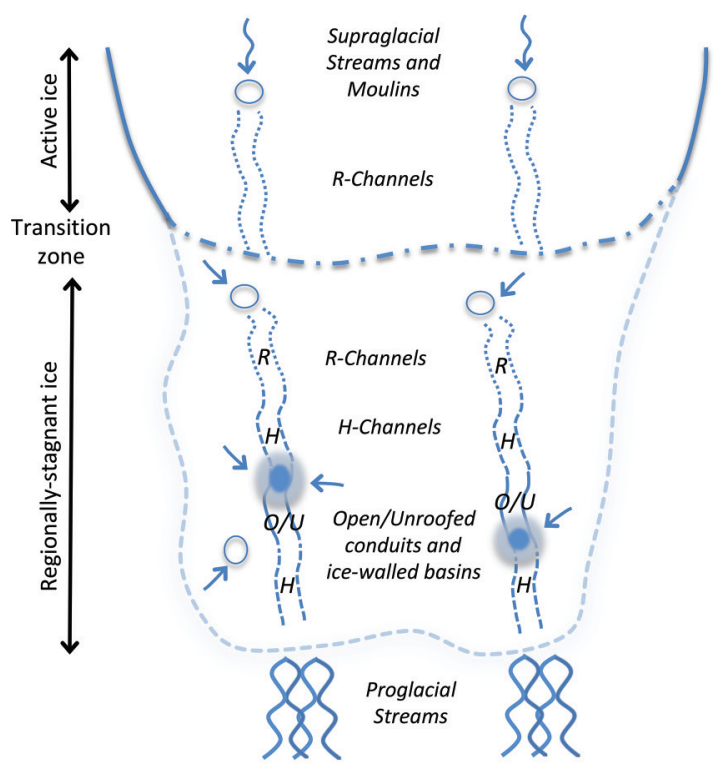

Keewatin. However, we maintain that the step-wise sequential retreat model (as currently formulated and summarized by Dyke 2004) is untenable. We also conclude that available dating is not currently sufficient to differentiate independently, regional stagnation from rapid retreat. Appropriate interpretations of the landform record take on added significance to resolve these questions.

\section{Deglacial style, corridor-esker patterns and sediment fluxes}

Whether deglaciation occurred by sequential retreat, stagnation, or rapid retreat, all models can be tested against the expected flux of sediment toward an ice margin, and development of icemarginal glaciofluvial landforms, constrained by new awareness of corridor-esker systems (Figs. 14,15).

A proglacial sediment flux is expected from the short-conduit model, including the VPA model of Lewington et al. (2020a, 2020b), which invokes sheet flow beyond conduit margins as documented in an Icelandic jökulhlaup (cf. Flowers et al. 2004). Tunnel valley development, sediment transport, esker segments, and abundant proglacial sedimentation all occurred during this jökulhlaup (Burke et al. 2008). Outwash fans, plains, deltas, or subaqueous fans might also develop at ponded ice-marginal settings. Such short-conduit deposits scale to nearby areas of sediment sourcing to the outlet (Fig. 14b). While fewer ice-marginal deposits are expected in the "long-conduit" model, their size should be larger (e.g., Chantrey, McAlpine stratified moraines, Fig. 1), with longer flow paths (Fig. 15b; Lewington et al. 2020a), and with no supply limit from the ample sediment in western Keewatin.

The "short-conduit" model favoured by Lewington et al. (2020a, $2020 b)$ and others considers that eskers were deposited in the b) Expected Landform and

Sediment Record

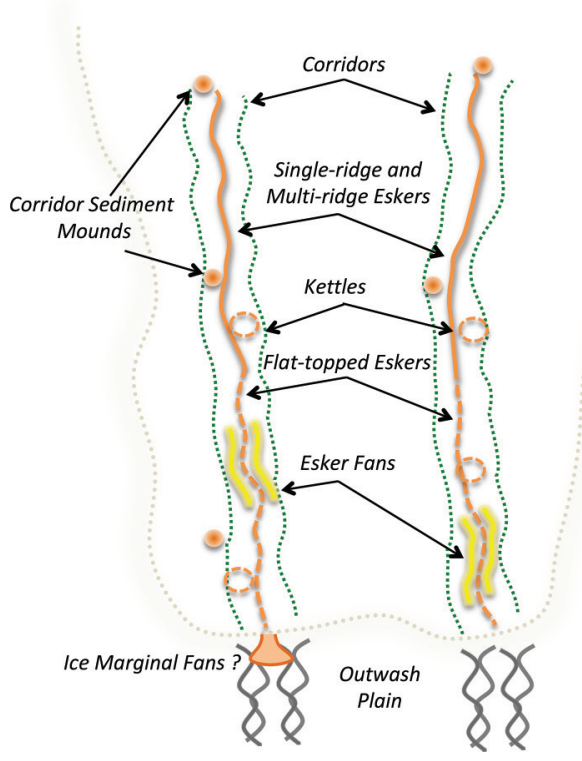

conduit near the ice margin during the final stages of Keewatin deglaciation. However, these conclusions are not supported by landform evidence of the purported ice margin. Rather, they rely on existing literature (e.g., Hebrand and Amark 1989; Storrar et al. 2014a, 2014b; Hewitt and Creyts 2019) that frequently assumes timetransgressive esker formation as an a priori premise. This premise is also reflected in cited modeling (Hewitt and Creyts 2019) that prescribe steady-state, continuous deposition of sediments near subglacial tunnels of an actively retreating ice sheet margin. Hence, in absence of ice-marginal landforms such as moraines, inferences of active ice-marginal retreat can only be supported by esker elements, which are in turn interpreted as short-conduit segments due to the assumption of active ice-marginal retreat.

Models of subglacial erosion predict subglacial sediment fluxes below the equilibrium line to the ice margin (cf. Alley et al. 1997; Boulton et al. 2009). Based on hydraulic modeling of shortconduit style eskers, some of this sediment may be stored within "bottlenecks" of eskers formed near the ice margin (Beaud et al. $2016,2018)$ that could limit proglacial sediment dispersal. In contrast, the regional integrated structure of western Keewatin corridor-esker systems (with long $>100 \mathrm{~km}$ corridors) and the general absence of ice-marginal landforms favours interpretations of "long-conduit" eskers (Cummings et al. 2011a). This creates a sediment flux conundrum: there is abundant evidence of erosion in and adjacent to corridors (Fig. 11); yet, the paucity of ice-marginal landforms in western Keewatin region suggests limited sediment fluxes toward the ice margin. Each corridor within the regional network potentially eroded sediment along $\sim 0.5-3 \mathrm{~km}$ wide swaths, up to 5-10 $\mathrm{m}$ thick (in places through $\sim 10-20 \mathrm{~m}$ thick 
drumlins), and potentially over lengths of $\sim 100 \mathrm{~km}$ or more. This eroded sediment is more than one order of magnitude greater compared with sediment volume observed in eskers, associated deposits, and limited proglacial sediment/moraines (Hardy et al. 2005; Lewington et al. 2020a). Corridor erosion should have resulted in ice-marginal fans across the western Keewatin (Fig. 14). These process and flux considerations frame the following key questions: (i) Where did the corridor- and esker-forming flows originate? (ii) What is the fate of the eroded sediment?

\section{Source(s) of water?}

Likely water sources include subglacial and supraglacial lakes. Theoretical support for evidence of subglacial lakes beneath the former LIS (e.g., Livingstone et al. 2013) was provided by Shoemaker's (1992a) analysis that depressions larger than $5 \mathrm{~km}$ in area (thousands of potential such depressions in the study area) were pre-disposed to store subglacial water. Given the likelihood of such depressions, even within low-relief Keewatin terrain, the build-up of subglacial water, reduced basal friction, thinning of the LIS over the Keewatin region likely occurred. Thinning would have limited the ability of the LIS to contain additional stored subglacial water, while supraglacial water would have readily gathered on the flatter ice surface (Fig. 12). This supraglacial meltwater would have drained rapidly to the ice base, similar to the periphery $(\sim 100 \mathrm{~km})$ of the modern Greenland ice sheet that has numerous surface melt-ponds draining to subglacial channel networks (e.g., Zwally et al. 2002; Flowers 2015; Palmer et al. 2015). More generally, Marren (2005) noted the importance of drainage events (jökulhlaups) and associated increase in sedimentation frequency to deglacial dynamics.

\section{Fate of sediments in eskers and corridors}

The regional-scale erosional record of western Keewatin corridors and the depositional record of inset eskers and ice-marginal sediment are not consistent with deposition within ice tunnels and in ice-marginal areas where tunnels debouched (fans/deltas) (Figs. 11, 14). A conservative estimated sediment budget deficit (an order of magnitude missing sediment per corridor kilometre) is not accounted for in mapped moraine sediment volumes, or volumes of sediment trapped in large lakes based on geophysical and core surveys conducted in the most eastern portion of GSL (Christoffersen et al. 2008). In flood terrain, such as the Channeled Scabland (Bretz 1923), sediment budgeting on the scoured Washington landscape did not account for the eroded/transported sediment, and it is now clear that most eroded sediment reached the Pacific submarine fan system beyond the ice margin (Brunner et al. 1999). We speculate, that the western Keewatin excess sediment may have been transported north, westward to the Arctic Ocean, or potentially westward and into a paleo-Mackenzie River, then Arctic Ocean. Nevertheless, better-constrained sediment budgets in the western Keewatin terrain are fundamental to understanding glaciohydraulic processes, including when and how corridors/ eskers formed.

\section{Summary and conclusion}

Extensive new field observations compiled with existing data, test and challenge a long-standing, widely invoked, conceptual model of sequential glacial retreat. Our observations indicate a late-stage (post till deposition) regional landscape scoured by meltwater, under a thinning ice sheet, where early meltwater sheet flow gave way to distributed flow, resulting in an anabranched network of erosional meltwater paths to corridors (channels) with inset eskers. Corridor erosional and depositional features are not clearly associated with predicted ice-marginal landforms, nor with sequential ice retreat. We conclude that the regional meltwater corridor-esker network is more compatible with a model of regional ice sheet stagnation (Shilts 1985; Shilts et al. 1987) rather than with sequential retreat (Dyke 2004; Lewington et al. 2020a, 2020b). In addition, inferred isochrones used to support sequential ice-marginal retreat and a deglacial chronology are unreliable in western Keewatin due to a paucity of dating control. The sparse marginal landform record is also insufficient to support sequential icemarginal retreat, or the prescribed Keewatin ice-marginal positions (e.g., Dyke et al. 2003). The likelihood that deglaciation proceeded under thin, stagnating regional ice, rather than marginal ice retreat, is an issue for reliable (LIS) ice sheet modelling.

\section{Acknowledgements}

We appreciate the thoughtful reviews by Chris Stokes, Bill Shilts, and by Greg Brooks (internal Geological Survey of Canada review). Lindsay Coffin worked on the figures. We thank Michel Plouffe for Geo-Mapping for Energy and Minerals funding for fieldwork in South Rae North and for legacy funding for open access publication and printed colour figures. Funding was also provided under MERA, Mineral and Energy Resource Assessment for proposed Thaidene Nene National Park Reserve in the area of the East Arm of GSL, Northwest Territories. Jeff Harris, John Glew, and John Shaw provided Figs. 8, 11 and 13, and 12, respectively. This is Geological Survey of Canada / Natural Resources Canada contribution number 20200745.

\section{References}

Alley, R.B., Cuffey, K.M., Evenson, E.B., Strasser, J.C., Lawson, D.E., and Larson, G.J. 1997. How glaciers entrain and transport basal sediment and physical constraints. Quaternary Science Reviews, 16: 1017-1038. doi:10.1016/S0277-3791(97) 00034-6.

Alley, R.B., Dupont, T.K., Parizek, B.R., Anandakrishnan, S., Lawson, D.E., Larson, G.J., and Evenson, E.B. 2006. Outburst flooding and the initiation of ice-stream surges in response to climatic cooling: A hypothesis. Geomorphology, 75: 76-89. doi:10.1016/j.geomorph.2004.01.011.

Aylsworth, J.M., and Shilts, W.W. 1989a. Glacial features around the Keewatin Ice Divide: Districts of Mackenzie and Keewatin. Geological Survey of Canada. Paper 88-24, 21. p.

Aylsworth, J.M., and Shilts, W.W. 1989b. Bedforms of the Keewatin Ice Sheet. Sedimentary Geology, 62: 407-428. doi:10.1016/0037-0738(89)90129-2.

Aylsworth, J.M., Shilts, W.W., Russell, H.A.J., and Pyne, D.M. 2012. Eskers around the Keewatin Ice Divide: Northwest Territories and Nunavut. Geological Survey of Canada. Open File 7047. doi:10.4095/290075.

Bartholomew, I., Nienow, P., Mair, D., Hubbard, A., King, M.A., and Sole, A. 2010. Seasonal evolution of subglacial drainage and acceleration in a Greenland outlet glacier. Nature Geoscience, 3: 408-411. doi:10.1038/ngeo863.

Bejan, A. 2000. Shape and Structure, from Engineering to Nature. Cambridge University Press. $324 \mathrm{p}$

Beaud, F., Flowers, G.E., and Venditti, J.G. 2016. Efficacy of bedrock erosion by subglacial water flow. Earth Surface Dynamics, 4: 125-145. doi:10.5194/ esurf-4-125-2016.

Beaud, F., Flowers, G.E., and Venditti, J.G. 2018. Modeling sediment transport in ice-walled subglacial channels and its implications for Esker Formation and proglacial sediment yields. Journal of Geophysical Research: Earth Surface, 123: 3206-3227. doi:10.1029/2018JF004779.

Bouchard, M. 1989. Subglacial landforms and deposits in central and northern Québec, Canada, with emphasis on Rogen moraines. Sedimentary Geology, 62(2-4): 293-308. doi:10.1016/0037-0738(89)90120-6.

Boulton, G.S., and Hindmarsh, R.C.A. 1987. Sediment deformation beneath glaciers: rheology and sedimentological consequences. Journal of Geophysical Research, 92: 9059-9082. doi:10.1029/JB092iB09p09059.

Boulton, G.S., Hagdorn, M., Maillot, P.B., and Zatsepin, S. 2009. Drainage beneath ice sheets: groundwater-channel coupling, and the origin of esker systems from former ice sheets. Quaternary Science Reviews, 28: 621-638. doi:10.1016/j.quascirev.2008.05.009.

Brennand, T.A. 1994. Macroforms, large bedforms and rhythmic sedimentation patterns in subglacial terrain, south-central Ontario: implications for esker genesis and meltwater regime. Sedimentary Geology, 91: 9-55. doi:10.1016| 0037-0738(94)90122-8

Brennand, T.A. 2000. Deglacial meltwater drainage and glaciodynamics: Inferences from Laurentide eskers. Geomorphology, 32: 263-293. doi:10.1016| S0169-555X(99)00100-2.

Brennand, T.A., and Sharpe, D.R. 1993. Ice-sheet dynamics and subglacial meltwater regime inferred from form and sedimentology of glaciofluvial systems: Victoria Island, District of Franklin, Northwest Territories. Canadian Journal of Earth Sciences, 30: 928-944. doi:10.1139/e93-078. 
Brennand, T.A., and Shaw, J. 1994. Tunnel channels and associated landforms: their implication for ice sheet hydrology. Canadian Journal of Earth Sciences, 31: 505-522. doi:10.1139/e94-045.

Brennand, T.A., Russell, H.A.J., and Sharpe, D.R. 2006. Tunnel channel character and evolution in central southern Ontario. In Glaciers and Earth's changing environment; P.G. Knight, Blackwell Publishing Limited, Oxford, United Kingdom, pp. 37-39.

Bretz, J.H. 1923. The Channeled Scabland of the Columbia Plateau. The Journal of Geology, 31: 617-649. doi:10.1086/623053.

Brunner, C., Normark, W., Zuffa, G., and Serra, F. 1999. Deep-sea sedimentary record of the late Wisconsin cataclysmic floods from the Columbia River. Geology, 27: 463-466. doi:10.1130/0091-7613(1999)027<0463:DSSROT>2.3.CO;2.

Burke, M.J., Woodward, J., Russell, A.J., Fleisher, P.J., and Bailey, P.K. 2008. Controls on the sedimentary architecture of a single event englacial esker: Skeidararjokull, Iceland. Quaternary Science Reviews, 27: 18291847. doi:10.1016/j.quascirev.2008.06.012.

Burke, M.J., Brennand, T.A., and Perkins, A.J. 2012a. Transient subglacial hydrology of a thin ice sheet: insights from the Chasm esker, British Columbia. Quaternary Science Reviews, 58: 30-55. doi:10.1016/j.quascirev.2012.09.004.

Burke, M.J., Brennand, T.A., and Perkins, A.J. 2012b. Evolution of the subglacial hydrologic system beneath the rapidly decaying Cordilleran Ice Sheet caused by ice-dammed lake drainage: implications for meltwaterinduced ice acceleration. Quaternary Science Reviews, 50: 125-140. doi:10.1016/ j.quascirev.2012.07.005.

Campbell, J.E., Lauzon, G., Dyke, A.S., Haiblen, A.M., and Roy, M. 2016. Report of 2016 activities for the regional surficial geological mapping of the south Rae Craton, southeast NWT: GEM 2 South Rae Quaternary and Bedrock Project. Geological Survey of Canada. Open File 8143, 13 p. doi:10.4095/299391.

Campbell, J.E., McMartin, I., Normandeau, P.X., and Godbout, P.-M. 2019. Report of 2018 activities for the GEM-2 Rae project glacial history activity in the eastern Northwest Territories and the Kitikmeot and Kivalliq Regions, Nunavut. Geological Survey of Canada. Open File 8586, 18 p. doi:10.4095/ 314741.

Campbell, J.E., McCurdy, M.W., Lauzon, G., Regis, D., and Wygergangs, M. 2020. Field data, till composition, and ice-flow history, south Rae Craton, Northwest Territories: results from the GEM-2 South Rae project - Surficial Mapping activity. Geological Survey of Canada. Open File 8714, 1 zip file. doi: $10.4095 / 327218$

Clark, C.D. 2010. Emergent drumlins and their clones: from till dilatancy to flow instabilities. Journal of Glaciology, 56(200): 1011-1025. doi:10.3189/ 002214311796406068.

Clark, C.D., Knight, J.K., and Gray, J.T. 2000. Geomorphological reconstruction of the Labrador Sector of the Laurentide Ice Sheet. Quaternary Science Reviews, 19: 1343-1366. doi:10.1016/S0277-3791(99)00098-0.

Clayton, L., and Moran, S.R. 1974. A glacial process-form model. In Glacial geomorphology. Edited by D.R. Coates. State University of New York, Binghampton, NY, pp. 89-120.

Craig, B.G. 1964. Surficial geology of east-central District of Mackenzie. Geological Survey of Canada. Bulletin, 99: 41. p.

Craig, B.G., and Fyles, J.G. 1960. Pleistocene geology of Arctic Canada. Geological Survey of Canada. Paper 60-10, 21. p.

Christoffersen, P., Tulaczyk, S., Wattrus, N.J., Peterson, J., Quintana-Krupinski, N., Clark, C.D., and Sjunneskog, C. 2008. Large subglacial lake beneath the Laurentide Ice Sheet inferred from sedimentary sequences. Geology, 36(7): 563-566. doi:10.1130/G24628A.1.

Cofaigh, C. Ó. 1996. Tunnel valley genesis. Progress in Physical Geography: Earth and Environment, 20: 1-19. doi:10.1177/030913339602000101.

Cummings, D.I., Kjarsgaard, B.A., Russell, H.A.J., and Sharpe, D.R. $2011 a$. Eskers as mineral exploration tools. Earth-Science Reviews, 109: 32-43. doi:10.1016/j.earscirev.2011.08.001.

Cummings, D.I., Gorrell, G., Guilbault, J.-P., Hunter, J., Logan, C., Ponomarenko, D., et al. 2011b. Sequence stratigraphy of a glaciated basin fill, with a focus on esker sedimentation. Geological Society of America Bulletin, 123: 1478-1496. doi:10.1130/B30273.1.

Cutler, P.M., Colgan, P.M., and Mickelson, D.M. 2002. Sedimentologic evidence for outburst floods from the Laurentide Ice Sheet margin in Wisconsin, USA: Implications for tunnel-channel formation. Quaternary International, 90: 2340. doi:10.1016/S1040-6182(01)00090-8.

Dalton, A.S., Margold, M., Stokes, C.R., Tarasov, L., Dyke, A.S., Adams, R.S., et al. 2020. An updated radiocarbon-based ice margin chronology for the last deglaciation of the North American Ice Sheet Complex. Quaternary Science Reviews, 234: 106223. doi:10.1016/j.quascirev.2020.106223.

De Angelis, H., and Kleman, J. 2005. Palaeo-ice streams in the northern Keewatin sector of the Laurentide Ice Sheet. Annals of Glaciology, 42: 135144. doi:10.3189/172756405781812925.

Dow, C.F., Kulessa, B., Rutt, I.C., Tsai, V.C., Pimentel, S., Doyle, S.H., et al. 2015. Modeling of subglacial hydrological development following rapid supraglacial lake drainage. Journal of Geophysical Research: Earth Surface, 120(6): 1127-1147. doi:10.1002/2014JF003333. PMID:26640746.

Dredge, L.A., Ward, B.C., and Kerr, D.E. 1995. Surficial geology, Aylmer Lake, District of Mackenzie, Northwest Territories; Geological Survey of Canada, Map 1867A, scale 1:125 000.

Dyke, A.S. 2004. An outline of North American deglaciation with emphasis on central and northern Canada; In Quaternary Glaciations- Extent and
Chronology: Part II: North America. Developments in Quaternary Sciences, Vol. 2, Part B. Edited by J. Ehlers and P.L. Gibbard. Elsevier, p. 373-424.

Dyke, A.S., and Dredge, L.A., 1989. Quaternary geology of the northwestern Canadian Shield, Chap. 3: Quaternary geology of the Canadian Shield. In Quaternary Geology of Canada Greenland. Edited by R.J. Fulton. Geological Survey of Canada, Geology of Canada Series No. 1, 1989, pp. 189-214. doi:10.4095/127963.

Dyke, A.S., and Kerr, D.E. 2014. Reconnaissance surficial geology, Hanbury River, Northwest Territories, NTS 75-P; Geological Survey of Canada. Canadian Geoscience Map, 186: scale-scal1. 125 000, 1 sheet. doi:10.4095/293991.

Dyke, A.S., and Prest, V.K. 1987a. Paleogeography of northern North America, 18000 - 5000 Years Ago. Geological Survey of Canada, Map 1703A, map scale, 1: 12500000.

Dyke, A.S., and Prest, V.K. 1987b. Late Wisconsin and Holocene history of the Laurentide Ice Sheet. Géographie physique et Quaternaire, et Quaternaire, 41: 237-263. doi:10.7202/032681ar.

Dyke, A.S., Vincent, J.-S., Andrews, J.T., Dredge, L.A., and Cowan, W.R. 1989. The Laurentide Ice Sheet and introduction to the Quaternary geology of the Canadian Shield. In Quaternary Geology of Canada and Greenland. Edited by R.J. Fulton. Geological Survey of Canada, Geology of Canada, No. 1, pp. 178-189.

Dyke, A.S., Moore, A., and Robertson, L. 2003. Deglaciation of North America: Geological Survey of Canada Open File 1574. doi:10.4095/214399.

Flowers, G.E. 2015. Modelling water flow under glaciers and ice sheets. Proceedings of the Royal Society A: Mathematical, Physical and Engineering Sciences, 471(2176): 20140907. doi:10.1098/rspa.2014.0907.

Flowers, G.E., Björnsson, H., Pálsson, F., and Clarke, G.K.C. 2004. A coupled sheet-conduit mechanism for jökulhlaup propagation. Geophysical Research Letters, 31 doi:10.1029/2003GL019088

Fisher, T.G., and Russell, A.J. 2005. Introduction to reassessing the role of meltwater processes during Quaternary glaciations. Quaternary Science Reviews, 24: 2305-2307. doi:10.1016/j.quascirev.2005.04.003.

Gorrell, G., and Shaw, J. 1991. Deposition in an esker, bead and fan complex, Lanark, Ontario. Sedimentary Geology, 72: 285-314. doi:10.1016/0037-0738 (91)90016-7.

Haiblen, A.M. 2017. Glacial history and landform genesis in the Lac de Gras area, Northwest Territories. Simon Fraser University, unpublished MSc thesis, $136 \mathrm{p}$.

Hardy, F., Delgaty, J., and Martel, E. 2005. Drift exploration surveys in the Snowbird Lake area, NWT: kimberlite indicator minerals, gold, heavy minerals geochemistry, till geochemistry. Northwest Territories Geoscience Office, NWT Open File 2005-07.

Hebrand, M., and Amark, M. 1989. Esker formation and glacier dynamics in eastern Skane and adjacecnt areas, southern Sweden. Boreas, 18(1): 67-81. doi:10.1111/j.1502-3885.1989.tb00372.x.

Hewitt, I.J., and Creyts, T.T. 2019. A Model for the Formation of Eskers. Geophysical Research Letters, 46: 6673-6680. doi:10.1029/2019GL082304.

Hooke, R.L 1984. On the role of mechanical energy in maintaining subglacial water conduits at atmospheric pressure. Journal of Glaciology, 30(105): 180187. doi:10.1017/S0022143000005918.

Hooke, R., LeB, T., Laumann, J., and Kohler, 1990. Sub glacial water pressures and the shape of subglacial conduits. Journal of Glaciology, 36(122): 67-71. doi:10.1017/S0022143000005566.

Hubbard, B.P., Sharp, M.J., Willis, I.C., Nielsen, M.K., and Smart, C.C. 1995. Borehole water-level variations and the structure of the subglacial hydrological system at Haut Glacier d'Arolla, Valais, Switzerland. Journal of Glaciology, 41(139): 572-583. doi:10.1017/S0022143000034894.

Kamb, B., Raymond, C.F., Harrison, W.D., Engelhardt, H., Echelmeyer, K.A., Humphrey, N., et al. 1985. Glacier surge mechanism: 1982-1983 surge of Variegated Glacier. Science, 227: 469-479. doi:10.1126/science.227.4686.469. PMID:17733459.

Kehew, A.E., Piotrowski, J.A., and Jørgensen, F. 2012. Tunnel valleys: Concepts and controversies - A review. Earth-Science Reviews, 113: 33-58. doi:10.1016/j.earscirev.2012.02.002.

Kerr, D.E. 2014. Reconnaissance surficial geology, MacKay Lake, Northwest Territories, NTS 75-M; Geological Survey of Canada. Canadian Geoscience Map 206 (ed. prelim.), 1 sheet. doi:10.4095/295542.

Kerr, D.E., Knight, R.D., Sharpe, D.R., Cummings, D.I., and Kjarsgaard., B.A. 2013a. Surficial geology map, East Arm MERA study area. In Mineral and Energy Resource Assessment for the Proposed Thaidene Nene National Park Reserve in the Area of the East Arm of Great Slave Lake, Northwest Territories. Edited by D.F. Wright. E.J. Ambrose, D. Lemkow, G.F. Bonham-Carter. Geological Survey of Canada, Open File 7196, digital supplement 2, scale 1:500 000.

Kerr, D.E., Knight, R.D., Sharpe, D.R., and Cummings, D.I. 2013b. Surficial geology, Artillery Lake, Northwest Territories, NTS 75-O; Geological Survey of Canada, Canadian Geoscience Map 110, scale 1:125 000, 1 sheet, doi: $10.4095 / 292268$

Kerr, D.E., Knight, R.D., Sharpe, D.R., Cummings, D.I., Kjarsgaard, B.A., and Russell, H.A.J. 2013c. Dispersal and provenance of clasts in till and eskers in the Proposed National Park Reserve, East Arm of Great Slave Lake. In Mineral and Energy Resource Assessment for the Proposed Thaidene Nene National Park Reserve in the area of the East Arm of Great Slave Lake, Northwest Territories. Geological Survey of Canada. Open File 7196, pp. 261-277. 
Kerr, D.E., Knight, R.D., Sharpe, D.R., Cummings, D.I., and Kjarsgaard, B.A. 2014a. Surficial geology, Snowdrift, Northwest Territories, NTS 75-L; Geological Survey of Canada, Canadian Geoscience Map 137, scale 1:125 000, 1 sheet. doi: $10.4095 / 293423$.

Kerr, D.E., Knight, R.D., Sharpe, D.R., and Cummings, D.I. 2014b. Surficial geology, Reliance, Northwest Territories, NTS 75-K; Geological Survey of Canada, Canadian Geoscience Map 138, scale 1:125 000, 1 sheet. doi:10.4095/ 293424.

Kerr, D.E., Knight, R.D., Sharpe, D.R., and Cummings, D.I. 2014c. Reconnaissance surficial geology, Lynx Lake, Northwest Territories, NTS 75-J; Geological Survey of Canada, Canadian Geoscience Map 139, scale 1:125 000, 1 sheet. doi: $10.4095 / 293624$.

Kerr, D.E., Knight, R.D., Sharpe, D.R., and Cummings, D.I. 2014d. Surficial geology, Walmsley Lake, Northwest Territories, NTS 75-N; Geological Survey of Canada, Canadian Geoscience Map 140, scale 1:125 000, 1 sheet. doi: $10.4095 / 293773$.

Kjarsgaard, B.A., Lemkow, D., and Tella, S. 2013a. Bedrock geology map, East Arm MERA study area. In Mineral and Energy Resource Assessment for the Proposed Thaidene Nene National Park Reserve in the area of the East Arm of Great Slave Lake, Northwest Territories. Edited by D.F. Wright, E.J. Ambrose, D. Lemkow, and G.F. Bonham-Carter. Geological Survey of Canada, Open File 7196, Digital supplement 1, scale 1:250 000.

Kjarsgaard, B.A., Knight, R.D., Sharpe, D.R., Kerr, D.E., Cummings, D.I., Russell, H.A.J., and Lemkow, D. 2013b. Significance of indicator minerals from till and esker samples, Thaidene Nene MERA study area. In Mineral and Energy Resource Assessment for the Proposed Thaidene Nene National Park Reserve in the area of the East Arm of Great Slave Lake, Northwest Territories. Geological Survey of Canada. Open File 7196, pp. 279-312.

Kjarsgaard, B.A., Knight, R.D., Plourde, A.P., Sharpe D.R., and Lesemann J.-E. 2013c. Geochemistry of till samples, NTS 75-I, 75-J, 75-O, 75-P (Mary Frances Lake - Whitefish Lake -Thelon River area), Northwest Territories; Geological Survey of Canada, Open File 7351. doi:10.4095/292390.

Kjarsgaard, B.A., Plourde, A.P., Knight, R.D., and Sharpe, D.R. 2014. Geochemistry of regional surficial sediment samples from the Thelon River to the East Arm of Great Slave Lake, Northwest Territories, Canada; Geological Survey of Canada, Open File 7649. doi:10.4095/295195.

Kleman, J., Hätterstrand, C., Stroeven, A.P., Jansson, K., De Angelis, H., and Borgström, I. 2006. Reconstruction of paleo-ice sheets - inversion of their glacial geomorphological record. In Glacier science and environmental change. Edited by P.G. Knight, Blackwell Publishing, Oxford, Oxfordshire, pp. 192-198.

Knight, R.D., Kjarsgaard, B.A., Plourde, A.P., Sharpe D.R., and Lesemann J.-E. 2013. Significance of indicator minerals from till and esker samples, NTS 75-I, 75-J, 75-O, 75-P (Mary Frances Lake - Whitefish Lake - Thelon River area), Northwest Territories. Geological Survey of Canada, Open File 7540. doi:10.4095/293341.

Knight, R.D., Armstrong, L.F., Sharpe, D.R., Kerr, D.E., Kjarsgaard, B.A., and Cummings, D.I. 2017. A photographic record of the glaciated landscape for the proposed Thaidene Nene National Park Reserve, Great Slave Lake, Northwest Territories. Geological Survey of Canada, Open File, 82319 pages, doi:10.4095/305980.

Lee, H.A. 1959. Surficial geology of southern District of Keewatin and the Keewatin Ice Divide, Northwest Territories. Geological Survey of Canada Bulletin 51, 42 p. doi:10.4095/100573.

Lee, H.A., Craig, B.G., and Fyles, J.G. 1957. Keewatin Ice Divide. Geological Society of America Bulletin, 68: 1760-1761

Lelandais, T., Ravier, E., Pochat, S., Bourgeois, O., Clark, C., Mourgues, R., and Strzerzynski, P. 2018. Modelled subglacial floods and tunnel valleys control the life cycle of transitory ice streams. The Cryosphere, 12: 27592772. doi:10.5194/tc-12-2759-2018.

Lewington, E.L.M., Livingstone, S., Sole, A.J., Clark, C.D., and Ng, F. 2019. An automated method for mapping geomorphological expressions of former subglacial meltwater pathways (hummock corridors) from high-resolution digital elevation data. Geomorphology, 339: 70-86. doi:10.1016/j.geomorph. 2019.04.013.

Lewington, E.L., Livingstone, S.J., Clark, C.D., Sole, A.J., and Storrar, D.R. 2020a. Large-scale integrated subglacial drainage around the former Keewatin Ice Divide, Canada reveals interaction between distributed and channelized systems. The Cryosphere Discussion. [In press] doi:10.5194/tc2020-10.

Lewington, E.L.M., Livingstone, S.J., Clark, C.D., Sole, A.J., and Storrar, R. $2020 b$. A model for interaction between conduits and surrounding hydraulically connected distributed drainage based on geomorphological evidence from Keewatin. The Cryosphere, 14: 2949-2976. doi:10.5194/tc-14-2949-2020.

Levson, V.M., Ferbey, T., and Kerr, D.E. 2013. Reconnaissance surficial geology, Clarke River (south half), Northwest Territories, NTS 65-M; Geological Survey of Canada, Canadian Geoscience Map 157, scale 1:125 000, 1 sheet, doi:10.4095/ 292716.

Livingstone, S.J., Clark, C.D., and Tarasov, L. 2013. Modelling North American palaeo-subglacial lakes and their meltwater drainage pathways. Earth and Planetary Science Letters, 375: 13-33. doi:10.1016/j.epsl.2013.04.017.

Livingstone, S.J., and Clark, C.D. 2016. Morphological properties of tunnel valleys of the southern sector of the Laurentide Ice Sheet and implications for their formation. Earth Surface Dynamics, 4: 567-589. doi:10.5194/esurf-4567-2016.
Livingstone, S.J., Lewington, E.L.M., Clark, C.D., Storrar, R.D., Sole, A.J., McMartin, I., et al. 2020. A quasi-annual record of time-transgressive esker formation: implications for ice sheet reconstruction and subglacial hydrology. The Cryosphere Discussion, 14: 1989-2004. doi:10.5194/tc-14-1989-2020.

Lord, C.S., and Barnes, F.Q. 1954. Aylmer Lake, District of Mackenzie, Northwest Territories, Geological Survey of Canada, Map 1031A.

Mäkinen, J. 2003. Time-transgressive deposits of repeated depositional sequences within interlobate glaciofluvial (esker) sediments in Köyliö, SW Finland. Sedimentology, 50(2): 337-360.

Mäkinen, J., Kajuutti, K., Palmu, J.-P., Ojala, A., and Ahokangas, E. 2017. Triangularshaped landforms reveal subglacial drainage routes in SW Finland. Quaternary Science Reviews, 164: 37-53. doi:10.1016/j.quascirev.2017.03.024.

Margold, M., Stokes, C.R., and Clark, C.D. 2018. Reconciling records of ice streaming and ice margin retreat to produce a palaeographic reconstruction of the deglaciation of the Laurentide Ice Sheet. Quaternary Science Reviews, 189: 1-30. doi:10.1016/j.quascirev.2018.03.013.

Marren, P.M. 2005. Magnitude and frequency in pro-glacial rivers: A geomorphological and sedimentological perspective. Earth-Science Reviews, 70: 203-251. doi:10.1016/j.earscirev.2004.12.002.

Maynard, D., and Kerr, D.E. 2014. Reconnaissance surficial geology, Carey Lake, Northwest Territories, NTS 65-L; Geological Survey of Canada. Canadian Geoscience Map, 136: scale-scal1. 125 000, 1 sheet. doi:10.4095/293627.

McMartin, I. 2017. Till provenance across the terminus of the Dubawnt Lake ice stream, central Nunavut. Geological Survey of Canada, Current Research (Online) 2017-1: 1-16. doi:10.4095/299744.

McMartin, I., and Berman, R.G. 2015. Till composition across the MacAlpine Moraine System: results from the GEM-2 Thelon tectonic zone project, Nunavut (NTS 76-H and NTS 76-I); Geological Survey of Canada. Open File 7910, 1.zip file. doi:10.4095/296833.

Ojala, A.E.K., Peterson, G., Mäkinen, J., Johnson, M.D., Kajuutti, K., Palmu, J.P., et al. 2019. Ice-sheet scale distribution and morphometry of triangular shaped hummocks (murtoos): a subglacial landform produced during rapid retreat of the Scandinavian Ice Sheet. Annals of Glaciology, 60: 115-112. doi:10.1017| aog.2019.34.

Palmer, S., McMillan, M., and Morlighem, M. 2015. Subglacial lake drainage detected beneath the Greenland ice sheet. Nature Communications, 6(8408): 1-7. doi:1038/ncomms9408.

Perkins, A.J., Brennand, T.A., and Burke, M.J. 2016. Towards a morphogenetic classification of eskers: Implications for modelling ice sheet hydrology. Quaternary Science Reviews, 134: 19-38. doi:10.1016/j.quascirev.2015.12.015.

Peterson, G., and Johnson, M.D. 2018. Hummock corridors in the south-central sector of the Fennoscandian ice sheet, morphometry and pattern. Earth Surface Processes and Landforms, 43(4): 919-929. doi:10.1002/ esp.4294.

Peterson, G., Johnson, M., and Smith, C. 2017. Glacial geomorphology of the south Swedish uplands - focus on the spatial distribution of hummock tracts. Journal of Maps, 13(2): 534-544. doi:10.1080/17445647.2017.1336121.

Peterson, G., Johnson, M.D., Dahlgren, S., Påsse, T., and Alexanderson, H. 2018. Genesis of hummocks found in tunnel valleys: an example from Hörda, southern Sweden. GFF, 140(2): 189-201. doi:10.1080/11035897.2018. 1470199.

Piotrowski, J.A. 1997. Subglacial hydrology in north-western Germany during the last glaciation: groundwater flow, tunnel valleys and hydrological cycles. Quaternary Science Reviews, 16: 169-185. doi:10.1016/S0277-3791 (96)00046-7.

Prest, V.K. 1969. Retreat of Wisconsin and Recent ice in North America. Geological Survey of Canada Map, 1257A, scale 1:5 000000.

Prest, V.K., Grant, D.R., and Rampton, V.N. 1968. Glacial Map of Canada. Geological Survey of Canada, Map 1253A, scale 1:5 000000

Rampton, V.N. 2000. Large-scale effects of subglacial meltwater flow in the southern Slave Province, Northwest Territories, Canada. Canadian Journal of Earth Sciences, 37: 81-93. doi:10.1139/e99-110.

Rampton, V.N., and Sharpe, D.R. 2014. Detailed surficial mapping in selected areas of the southern Slave Province, Geological Survey of Canada, Open File 7562.

Russell, A.J., Roberts, M.J., Fay, H., Marren, P.M., Cassidy, N.J., Tweed, F.S., and Harris, T. 2006. Icelandic jökulhlaups impacts: Implications for icesheet hydrology, sediment transfer and geomorphology. Geomorphology, 75: 33-64. doi:10.1016/j.geomorph.2005.05.018.

Russell, A.J., Gregory, A.R., Large, A.R., Fleisher, P.J., and Harris, T.D. 2007. Tunnel channel formation during the 1996 Novemberjökulhlaup, Skeiðarárjökull, Iceland. Annals of Glaciology, 45: 95-103. doi:10.3189/172756407782282552.

Sharpe, D.R., Lesemann, J.-E. Knight, R.D., Kjarsgaard, B.A., and Plourde, A.P. 2014. Glacial landscape architecture and sediment sampling, Mary Frances Lake - Whitefish Lake - Thelon River area (NTS 75-I, 75-J, 75-O, 75-P), Northwest Territories, Canada; Geological Survey of Canada, Open File 7554. doi:10.4095/295461.

Sharpe, D.R., Kjarsgaard, B.A., Knight, R.D., Russell, H.A.J., and Kerr, D.E. 2017. Glacial dispersal and flow history, East Arm area of Great Slave Lake, NWT, Canada. Quaternary Science Reviews, 165: 49-72. doi:10.1016/ j.quascirev.2017.04.011.

Shaw, J. 1983. Drumlin formation related to inverted melt-water erosional marks. Journal of Glaciology, 29: 461-479. doi:10.3189/S0022143000030367.

Shaw, J. 1994. Hairpin erosional marks, horseshoe vortices and subglacial erosion. Sedimentary Geology, 91: 269-284. doi:10.1016/0037-0738(94)90134-1. 
Shaw, J. 2002. The Meltwater Hypothesis for Subglacial Bedforms. Quaternary International, 90(1): 5-22. doi:10.1016/S1040-6182(01)00089-1.

Shaw, J., Sharpe, D.R., and Harris, J. 2010. A flowline map of glaciated Canada based on remote sensing data. Canadian Journal of Earth Sciences, 47(1): 89101. doi:10.1139/E09-068.

Shilts, W.W. 1985. Geological models for the configuration, history and style of disintegration of the Laurentide Ice Sheet. In Models in Geomorphology: The Binghampton Symposia in Geomorphology. Edited by M.J. Woldenberg. George Allen and Unwin, London, pp. 73-91.

Shilts, W.W., Cunningham, C.M., and Kaszycki, C.A. 1979. Keewatin Ice SheetRe-evaluation of the traditional concept of the Laurentide Ice Sheet. Geology, 7: 537-541. doi:10.1130/0091-7613(1979)7<537:KISOTT >2.0.CO;2.

Shilts, W.W., Aylsworth, J.M., Kaszycki, C.A., and KlassenR, A. 1987. Geomorphic systems in North America. Geological Society of America. Centennial, 2: 119-161.

Shoemaker, E.M. 1991. On the formation of large subglacial lakes. Canadian Journal of Earth Sciences, 28: 1975-1981. doi:10.1139/e91-179.

Shoemaker, E.M. 1992a. Subglacial floods and the origin of low relief ice sheet lobes. Journal of Glaciology, 38: 105-112. doi:10.1017/S0022143000009643.

Shoemaker, E.M. 1992b. Water sheet outburst floods from the Laurentide Ice Sheet. Canadian Journal of Earth Sciences, 29: 1250-1264. doi:10.1139/e92100.

Shreve, R.L. 1985. Esker characteristics in terms of glacial physics, Katahdin esker system, Maine. Geological Society of America Bulletin, 96: 639646.

Sjogren, D.B., Fisher, T.G., Taylor, L.D., Jol, H.M., and Munro-Stasiuk, M.J. 2002. Incipient tunnel channels. Quaternary International, 90: 41-56. doi:10.1016/S1040-6182(01)00091-X.

Stea, R., and Kerr, D.E. 2014. Reconnaissance surficial geology, Beaverhill Lake, Northwest Territories, NTS 75-I; Geological Survey of Canada. Canadian Geoscience Map, 141: 1 sheet (ed. 2, Prelim.), scale 1:125 000. doi:10.4095/ 293923.

St-Onge, D.A. 1984. Surficial deposits of the Redrock Lake area, District of Mackenzie, In, Current Research, Part A, Geological Survey of Canada. Paper 84-1A, pp. 271-276.

Stokes, C.R., and Clark, C.D. 1999. Geomorphological criteria for identifying Pleistocene ice streams. Annals of Glaciology, 28: 67-74. doi:10.3189| 172756499781821625

Stokes, C.R., and Clark, C.D. 2003. The Dubawnt Lake paleo-ice stream: evidence for dynamic ice sheet behaviour on the Canadian Shield and insights regarding the controls on ice-stream location and vigour. Boreas, 32: 263-279. doi:10.1111/j.1502-3885.2003.tb01442.x.

Stokes, C.R., Clark, C.D., Lian, O., and Tulaczyk, S. 2006. Geomorphological map of ribbed moraine on the Dubawnt Lake Ice Stream bed: a signature of ice stream shut-down? Journal of Maps, 2: 1-9. doi:10.4113/jom.2006.43.

Stokes, C.R., Clark, C.D., and Storrar, R. 2009. Major changes in ice stream dynamics during deglaciation of the north-western margin of the Laurentide Ice Sheet. Quaternary Science Review, 28(7-8): 721-738. doi:10.1016/j. quascirev.2008.07.019.
Stokes, C.R., Spagnolo, M., Clark, C.D., Tulaczyk, S.M., Ó Cofaigh, C., Lian, O., and Dunstone, R.B. 2013. Formation of Mega-scale Glacial Lineations on the Dubawnt Lake Ice Stream bed: 1. Size, Shape and Spacing from a Large Remote Sensing Dataset. Quaternary Science Reviews, 77: 190-209. doi:10.1016/j.quascirev.2013.06.003.

Storrar, R.D., and Livingstone, S.J. 2017. Glacial geomorphology of the northern Kivalliq region, Nunavut, Canada, with an emphasis on meltwater drainage systems. Journal of Maps, 13: 153-164. doi:10.1080/17445647. 2017.1279081.

Storrar, R.D., Stokes, C.R., and Evans, D.J.A. 2013. A map of Canadian eskers from Landsat satellite imagery. Journal of Maps, 9: 456-473. doi:10.1080/ 17445647.2013.815591.

Storrar, R.D., Stokes, C.R., and Evans, D.J.A. 2014a. Increased channelization of subglacial drainage during deglaciation of the Laurentide Ice Sheet. Geology, 42(3): 239-242. doi:10.1130/G35092.1.

Storrar, R.D., Stokes, C.R., and Evans, D.J.A. 2014b. Morphometryand pattern of a large sample $(>20,000)$ of Canadian eskers and implications for subglacial drainage beneath ice sheets. Quaternary Science Reviews, 105: 1-25. doi:10.1016/j.quascirev.2014.09.013.

Tarasov, L., and Peltier, W.R. 2004. A geophysically constrained large ensemble analysis of the deglacial history of the North American ice-sheet complex. Quaternary Science Reviews, 23(3-4): 359-388. doi:10.1016/j.quascirev.2003. 08.004

Tarasov, L., Dyke, A.S., Neal, R.M., and Peltier, W.R. 2012. A data-calibrated distribution of deglacial chronologies for the North American ice complex from glaciological modelling. Earth and Planetary Science Letters, 315-316: 30-40. doi:10.1016/j.eps1.2011.09.010.

Tyrell, J.W. 1902. Report on an exploratory survey between Great Slave Lake and Hudson Bay. Department Interior. Bulletin, 1262 p. Government Print Bureau, Ottawa. Available from https://barrenlands.library.utoronto.ca/ islandora/object/barrenlands\%3AT10002.

Utting, D.J., Ward, B.C., and Little, E.C. 2009. Genesis of hummocks in glaciofluvial corridors near the Keewatin Ice Divide, Canada. Boreas, 10: 471-481. doi:10.1111/j.1502-3885.2008.00074.x.

Van der Vegt, P., Janszen, A., and Moscariello, A. 2012. Tunnel valleys: current knowledge and future perspectives. Geological Society, Special Publications, London. 368: 75-97.

Ward, B.C., Dredge, L.A., and Kerr, D.E. 1997. Surficial geology, Lac de Gras, District of Mackenzies, Northwest Territories. Geological Survey of Canada, 1, 76: 125-000. (NTS D.)

Wingfield, R. 1990. The origin of major incisions within the Pleistocene deposits of the North Sea. Marine Geology, 91: 31-52. doi:10.1016/00253227(90)90131-3.

Wilson, J.T. 1939. Eskers northeast of Great Slave Lake. Transactions of the Royal Society of Canada. ser. 3, sect 4, 33: 119-130.

Zwally, H.J., Abdalati, W., Herring, T., Larson, K., Saba, J., and Seffen, K. 2002. Surface melt induced acceleration of Greenland Ice-sheet flow. Science, 297: 218-222. doi:10.1126/science.1072708. PMID:12052902. 